\title{
Cloud-scale model intercomparison of chemical constituent transport in deep convection
}

\author{
M. C. Barth ${ }^{1}$, S.-W. Kim ${ }^{1, *}$, C. Wang ${ }^{2}$, K. E. Pickering ${ }^{3, * *}$, L. E. Ott ${ }^{3, * *}$, G. Stenchikov ${ }^{4}$, M. Leriche ${ }^{5, * * *}$, S. Cautenet ${ }^{5}$, \\ J.-P. Pinty ${ }^{6}$, Ch. Barthe $^{6}$, C. Mari ${ }^{6}$, J. H. Helsdon ${ }^{7}$, R. D. Farley ${ }^{7}$, A. M. Fridlind ${ }^{8, * * * *}$, A. S. Ackerman ${ }^{8, * * *}$, \\ V. Spiridonov ${ }^{9}$, and B. Telenta ${ }^{10}$ \\ ${ }^{1}$ National Center for Atmospheric Research, Boulder, CO, USA \\ ${ }^{2}$ Massachusetts Institute of Technology, Cambridge, MA, USA \\ ${ }^{3}$ University of Maryland, College Park, MD, USA \\ ${ }^{4}$ Rutgers University, New Brunswick, NJ, USA \\ ${ }^{5} \mathrm{CNRS} /$ University Blaise-Pascal, Clermont-Ferrand, France \\ ${ }^{6}$ CNRS/Paul Sabatier University, Toulouse, France \\ ${ }^{7}$ South Dakota School of Mines and Technology, Rapid City, SD, USA \\ ${ }^{8}$ NASA-Ames Research Center, Moffett Field, CA, USA \\ ${ }^{9}$ Hydrometeorological Institute, Skopje, Macedonia \\ ${ }^{10}$ SENES Consultant Ltd., Toronto, Canada \\ *now at: ESRL/CSD and CIRES, University of Colorado, Boulder, CO, USA \\ *** now at: NASA-Goddard Space Flight Center, Greenbelt, MD, USA \\ **** now at: CNRS/Paul Sabatier University, Toulouse, France \\ *****now at: NASA-GISS, New York City, NY, USA
}

Received: 14 May 2007 - Published in Atmos. Chem. Phys. Discuss.: 8 June 2007

Revised: 6 September 2007 - Accepted: 8 September 2007 - Published: 18 September 2007

\begin{abstract}
Transport and scavenging of chemical constituents in deep convection is important to understanding the composition of the troposphere and therefore chemistryclimate and air quality issues. High resolution cloud chemistry models have been shown to represent convective processing of trace gases quite well. To improve the representation of sub-grid convective transport and wet deposition in large-scale models, general characteristics, such as species mass flux, from the high resolution cloud chemistry models can be used. However, it is important to understand how these models behave when simulating the same storm. The intercomparison described here examines transport of six species. $\mathrm{CO}$ and $\mathrm{O}_{3}$, which are primarily transported, show good agreement among models and compare well with observations. Models that included lightning production of $\mathrm{NO}_{\mathrm{x}}$ reasonably predict $\mathrm{NO}_{\mathrm{x}}$ mixing ratios in the anvil compared with observations, but the $\mathrm{NO}_{\mathrm{x}}$ variability is much larger than that seen for $\mathrm{CO}$ and $\mathrm{O}_{3}$. Predicted anvil mixing ratios of the soluble species, $\mathrm{HNO}_{3}, \mathrm{H}_{2} \mathrm{O}_{2}$, and $\mathrm{CH}_{2} \mathrm{O}$, exhibit significant differences among models, attributed to different schemes in these models of cloud processing including the role of the
\end{abstract}

Correspondence to: M. C. Barth

(barthm@ucar.edu) ice phase, the impact of cloud-modified photolysis rates on the chemistry, and the representation of the species chemical reactivity. The lack of measurements of these species in the convective outflow region does not allow us to evaluate the model results with observations.

\section{Introduction}

Convective processing of trace gas species is an important means of moving chemical constituents rapidly between the boundary layer and free troposphere, and is also an effective way of cleansing the atmosphere through wet deposition. Because of these two processes, the effect of convection on chemical species is critical to our understanding of chemistry-climate studies, air quality studies, and the effects of acidic precipitation on the earth's surface.

In large-scale models convective parameterizations have been developed primarily on the basis of mass and heat fluxes. An intercomparison of several convective parameterizations used in both global and regional scale models shows that there is significant variability among the parameterizations (Xie et al., 2002; Tost et al., 2006). Lawrence and Rasch (2005) compared tracer transport in deep convection

Published by Copernicus Publications on behalf of the European Geosciences Union. 
for plume ensemble and bulk formulations of convective transport parameterizations. Their results showed differences in the upper troposphere of up to $25 \%$ between the plume ensemble and bulk formulations of convective transport for the July monthly mean mixing ratios of decaying, insoluble scalars. At shorter averaging times, the differences between the two formulations are even greater. Clearly there is a need to improve the parameterizations of trace gas transport by convection in the global models.

On the other hand, many previous studies using high resolution cloud-resolving models (or convective cloud models) have shown that case-specific simulations are able to represent the storm structure and kinematics, such as radar reflectivity, wind speed and direction, and outflow heights. Convective cloud models coupled with chemistry simulate the redistribution of passive trace gas species well (e.g. Pickering et al., 1996; Stenchikov et al., 1996; Wang and Prinn, 2000; Skamarock et al., 2000; DeCaria et al., 2000). The cloudresolving models, when incorporated with reasonably comprehensive chemistry, can also provide details of cloud processing of soluble chemical species as well as tropospheric production/destruction of short-lived species including critical hydrogen oxides precursors and aerosols influenced by the existence of convection (e.g. Wang and Chang, 1993b, c; Wang and Crutzen, 1995; Wang and Prinn, 2000; Barth et al., 2001, 2007; Ekman et al., 2004, 2006; DeCaria et al., 2005). Adequate representation of cloud processing of reactive and soluble species in the large scale models is still in demand.

Convective transport and wet deposition of chemical species in large-scale models are sub-grid scale processes and thus have to be implicitly represented by various parameterizations using grid resolving variables. To improve these parameterizations, the high resolution and process-oriented convective-scale model can be used to obtain general characteristics of these sub-grid processes in particular when multiple cloud resolving models are involved. Before gathering convective transport characteristics of tracers from multiple cloud resolving model simulations of different storms, it is important to understand how these models behave when simulating the same storm. Results presented here as part of the 6th International Cloud Modeling Workshop (Grabowski, 2006) Case 5 intercomparison provide a means to make an initial comparison of a variety of cloud resolving models coupled with chemistry.

The Chemistry Transport by Deep Convection Intercomparison case was designed to assess the capability of each model to transport different chemical species from the boundary layer to the upper troposphere including the entrainment of free tropospheric air. Parameterizations of lightning-produced $\mathrm{NO}_{\mathrm{x}}$ are part of the intercomparison exercise. Carbon monoxide $(\mathrm{CO})$ and ozone $\left(\mathrm{O}_{3}\right)$ are compared as tracers of transport because the lifetime of the storm (hours) is shorter than the chemical lifetime (days to months) of these species. Nitrogen oxides $\left(\mathrm{NO}_{\mathrm{x}}=\mathrm{NO}+\mathrm{NO}_{2}\right)$ are examined to assess transformation, transport, and $\mathrm{NO}_{\mathrm{x}}$ produc- tion by lightning. Nitric acid $\left(\mathrm{HNO}_{3}\right)$, hydrogen peroxide $\left(\mathrm{H}_{2} \mathrm{O}_{2}\right)$, and formaldehyde $\left(\mathrm{CH}_{2} \mathrm{O}\right)$ are compared to evaluate chemical transformation and transport of soluble and reactive species.

\section{Description of the case}

The 10 July 1996 STERAO (Stratospheric-Tropospheric Experiment: Radiation, Aerosols, and Ozone) case was observed near the Wyoming-Nebraska-Colorado border. The isolated storm evolved from a multicellular thunderstorm to a quasi-supercell. Observations of the storm were obtained from several platforms including the CSU CHILL radar, the ONERA lightning interferometers, the NOAA WP3D aircraft, and the UND Citation aircraft. These observations are summarized by Dye et al. (2000). Because the 10 July STERAO storm has a comprehensive set of observations and previous model simulations have proven to successfully represent the observed storm (Skamarock et al., 2000, 2003; Barth et al., 2001, 2007), this case is appropriate for intercomparison of cloud chemistry models.

The simulations performed for the intercomparison mimic those described by Skamarock et al. (2000) and Barth et al. $(2001,2007)$. The environment was assumed to be homogeneous, thus a single profile was used for initialization. The initial profiles of the meteorological data were obtained from sonde and aircraft data (Skamarock et al., 2000). To start the convection quickly so that the intercomparison could focus on chemical species transport, the convection was initiated with 3 warm bubbles $\left(3^{\circ} \mathrm{C}\right.$ perturbation) oriented in a NW to SE line following Skamarock et al. (2000). Their choice of three bubbles was based on obtaining a good representation of the storm structure and evolution (particularly the transition from a multicell storm to a quasi-supercell) with their cloud model. Using the same initiation protocol in each of the participating models will likely produce different storm structures and evolution because of the different methodologies employed in each model. Showing how each model responds to the same initiation is valuable in itself. Simulations were integrated for a 3-h period.

The initial profiles (Fig. 1) of the chemical species are primarily from the aircraft observations obtained outside of cloud. CO is a surface tracer with a surface mixing ratio of $135 \mathrm{nmol} \mathrm{mol}^{-1}$. CO mixing ratios in the free troposphere range from $90-110 \mathrm{nmol} \mathrm{mol}^{-1}$ in the mid-troposphere and $50-90 \mathrm{nmol} \mathrm{mol}^{-1}$ in the upper troposphere. $\mathrm{O}_{3}$ mixing ratios are fairly constant with height to about $7 \mathrm{~km}$ mean sea level (m.s.l.), above which $\mathrm{O}_{3}$ mixing ratios rapidly increase into the stratosphere. The initial profile of $\mathrm{NO}_{\mathrm{x}}$ is based on $\mathrm{NO}$ measurements outside of cloud. $\mathrm{NO}_{\mathrm{x}}$ mixing ratios are $\sim 500 \mathrm{pmol} \mathrm{mol}^{-1}$ near the surface, but quickly decrease to values near $50 \mathrm{pmol} \mathrm{mol}^{-1}$ in the mid troposphere. At high altitudes $\mathrm{NO}_{\mathrm{x}}$ increases to $200 \mathrm{pmol} \mathrm{mol}^{-1}$. $\mathrm{CH}_{2} \mathrm{O}$ and $\mathrm{H}_{2} \mathrm{O}_{2}$ initial mixing ratios are from the low-flying aircraft that are 

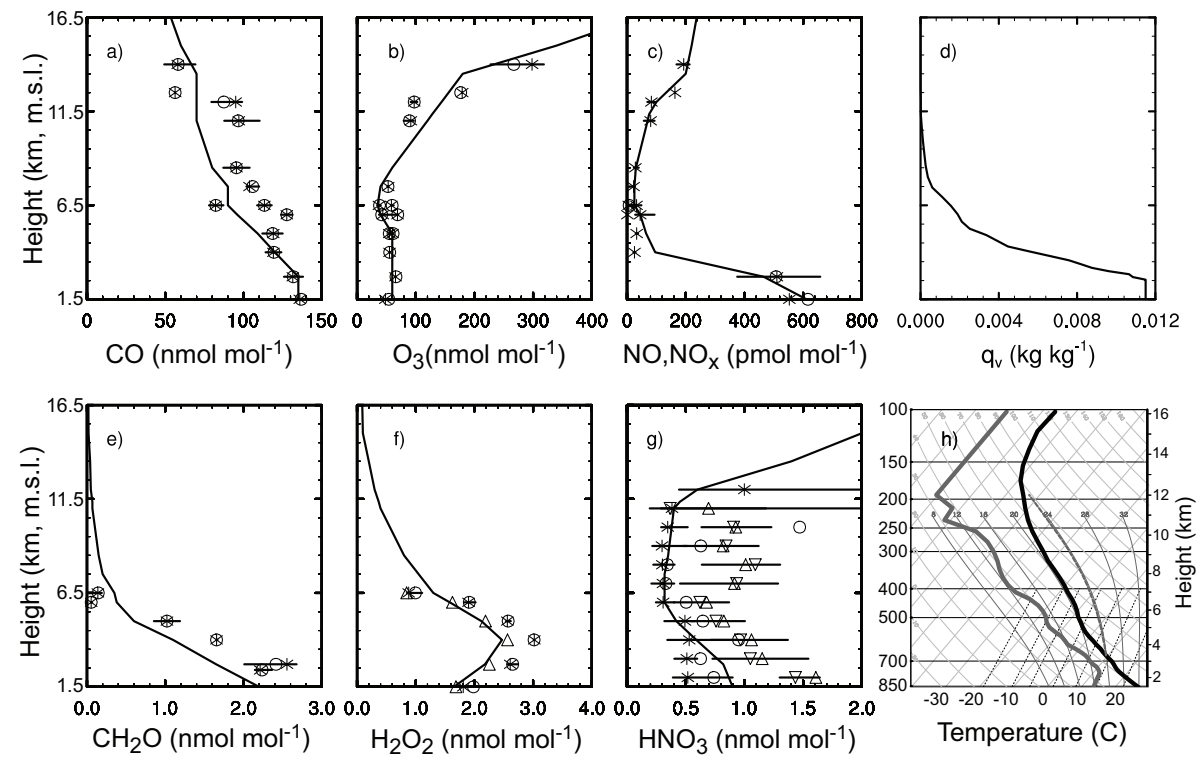

Fig. 1. Initial profiles (black lines) of the chemical species simulated in the case. Circles (average) and asterisks (median) points are from aircraft (UND Citation above $5 \mathrm{~km}$, m.s.l.; NOAA WP3D below $7 \mathrm{~km}$, m.s.l.) observations outside of cloud near the $10 \mathrm{July} 1996$ storm. In panel (c), the points are observed $\mathrm{NO}$ mixing ratios and the line is the $\mathrm{NO}_{\mathrm{x}}$ profile used to initialize the models. In (d), $q_{v}$ is water vapor. On the $\mathrm{H}_{2} \mathrm{O}_{2}$ profile plot (f), points are for total peroxide measurements except for the triangles which are for 0.85 times the total peroxide. Circles (average) and asterisks (median) on the $\mathrm{HNO}_{3}$ profile plot (g) are from $\mathrm{NO}_{\mathrm{y}}$ measurements taken aboard the NASA DC8 during the SUCCESS field campaign in April-May 1996. Triangles (average) and nablas (median) on the $\mathrm{HNO}_{3}$ profile plot (g) are from $\mathrm{NO}_{\mathrm{y}}$ measurements taken aboard the NCAR Sabreliner during the ELCHEM field campaign in August 1989. In (h) a skew-T diagram shows the initial thermodynamic state.

combined with values obtained from the literature for high altitudes (Cohan et al., 1999; these initial profiles are in line with observations reported by Snow et al., 2007). $\mathrm{CH}_{2} \mathrm{O}$ decreases from the surface to $<200 \mathrm{pmol} \mathrm{mol}^{-1}$ in the midtroposphere. $\mathrm{H}_{2} \mathrm{O}_{2}$ mixing ratios peak near the top of the boundary layer then rapidly decrease in the mid to upper troposphere. $\mathrm{HNO}_{3}$ mixing ratios are based on $\mathrm{NO}_{\mathrm{y}}$ measurements from the NASA SUCCESS (Jaeglé et al., 1998) and the NSF ELCHEM (Ridley et al., 1994) field campaigns.

\section{Description of the models used in the intercomparison}

Eight modeling groups submitted results for comparison. Tables 1 and 2 identify each group and key characteristics of their models. All models were configured to resolve the deep convection with fine scale resolution so that subgrid convective parameterizations were not needed. Although the models described below include a radiation scheme, the radiation parameterization was not activated except for the C. Wang model. The radiation effects on the cloud dynamics should be small for the short $(3 \mathrm{~h})$ simulation of deep convection.
3.1 WRF with aqueous chemistry (WRF-AqChem, M. Barth and S.-W. Kim)

A simple gas and aqueous chemistry scheme has been incorporated into the Weather Research and Forecasting (WRF) model (Barth et al., 2007). The WRF model solves the conservative (flux-form), nonhydrostatic compressible equations using a split-explicit time-integration method based on a 3rd order Runge-Kutta scheme (Skamarock et al., 2005; Wicker and Skamarock, 2002). Scalar transport is integrated with the Runge-Kutta scheme using 5th order (horizontal) and 3rd order (vertical) upwind-biased advection operators. Transported scalars include water vapor, cloud water, rain, cloud ice, snow, graupel (or hail), and chemical species. Aerosols are not included in this version of WRF.

The cloud microphysics is described by the single moment (bulk water) approach (Lin et al., 1983). Mass mixing ratios of cloud water, rain, ice, snow, and hail are predicted. Cloud water and ice are monodispersed and rain, snow, and hail have prescribed inverse exponential size distributions. For the simulations performed here, hail hydrometeor characteristics $\left(\rho_{h}=900 \mathrm{~kg} \mathrm{~m}^{-3}, \mathrm{~N}_{o}=4 \times 10^{4} \mathrm{~m}^{-4}\right)$ are used.

The chemistry represents 28 gas-phase and 15 aqueousphase reactions (Barth et al., 2007) of 15 chemical species: methane $\left(\mathrm{CH}_{4}\right), \mathrm{CO}, \mathrm{O}_{3}$, hydroxyl radical $(\mathrm{OH})$, hydroperoxy radical $\left(\mathrm{HO}_{2}\right)$, methylhydroperoxy radical $\left(\mathrm{CH}_{3} \mathrm{OO}\right)$, 
Table 1. Description of the model dynamics, microphysics and configuration used for the simulations.

\begin{tabular}{|c|c|c|c|}
\hline Model & Dynamics and thermodynamics & Cloud microphysics and aerosols & Configuration \\
\hline $\begin{array}{l}\text { WRF-AqChem } \\
\text { (Barth, Kim) }\end{array}$ & 3-D, flux-form, Runge-Kutta & $\begin{array}{l}2 \text { liquid, } 3 \text { ice, predict } \mathrm{M} \\
\text { (Lin et al., 1983) } \\
\text { hail characteristics } \\
\text { no aerosols }\end{array}$ & $\begin{array}{l}160 \times 160 \times 20 \mathrm{~km}^{3} \\
1 \times 1 \mathrm{~km}^{2} \text { horizontal } \\
50 \text { vertical levels } \\
10 \text { s time step }\end{array}$ \\
\hline C. Wang & $\begin{array}{l}\text { 3-D pseudo-elastic, } \\
\text { ice-liquid T } \\
\text { modified Bott advec. }\end{array}$ & $\begin{array}{l}2 \text { liquid, } 2 \text { ice, predict } \mathrm{N} \text { and } \mathrm{M} \\
\text { graupel characteristics, Prognostic } \\
\mathrm{CCN} \text { and IN }\end{array}$ & $\begin{array}{l}145 \times 120 \times 20 \mathrm{~km}^{3} \\
1 \times 1 \times 0.4 \mathrm{~km}^{3} \text { resol. } \\
3 \text { s time step }\end{array}$ \\
\hline $\begin{array}{l}\text { U. Md/GCE } \\
\text { (Pickering, Ott, Stenchikov) }\end{array}$ & $\begin{array}{l}\text { 3-D GCE Model } \\
\text { (Tao and Simpson, 1993) } \\
\text { MPDATA and van Leer advection }\end{array}$ & $\begin{array}{l}2 \text { liquid, } 3 \text { ice, predict } \mathrm{M} \\
\text { (Lin et al., 1983) } \\
\text { hail characteristics } \\
\text { no aerosols }\end{array}$ & $\begin{array}{l}360 \times 328 \times 25 \mathrm{~km}^{3} \\
2 \times 2 \times 0.5 \mathrm{~km}^{3} \text { resol. } \\
3,15 \text {, and } 30 \mathrm{~s} \text { time step }\end{array}$ \\
\hline $\begin{array}{l}\text { RAMS } \\
\text { (Leriche, Cautenet) }\end{array}$ & $\begin{array}{l}\text { 3-D, anelastic } \\
\text { 2nd order flux conservative ad- } \\
\text { vec. }\end{array}$ & $\begin{array}{l}2 \text { liquid, } 3 \text { ice, predict } \mathrm{N} \text { and } \mathrm{M} \\
\text { (Meyers et al., 1997) } \\
\text { hail characteristics } \\
\text { no aerosols }\end{array}$ & $\begin{array}{l}120 \times 120 \times 20 \mathrm{~km}^{3} \\
1 \times 1 \mathrm{~km}^{2} \text { resolution } \\
50 \text { vertical levels } \\
5 \mathrm{~s} \text { time step }\end{array}$ \\
\hline $\begin{array}{l}\text { Meso-NH } \\
\text { (Pinty, Barthe Mari) }\end{array}$ & $\begin{array}{l}\text { 3-D, anelastic } \\
\text { MPDATA advection }\end{array}$ & $\begin{array}{l}2 \text { liquid, } 3 \text { ice, predict } \mathrm{M} \\
\text { (Pinty and Jabouille, 1998) } \\
\text { graupel characteristics } \\
\text { no aerosols }\end{array}$ & $\begin{array}{l}160 \times 160 \times 25 \mathrm{~km}^{3} \\
1 \times 1 \mathrm{~km}^{2} \text { resolution } \\
50 \text { vertical levels } \\
2 \mathrm{~s} \text { time step }\end{array}$ \\
\hline $\begin{array}{l}\text { SDSMT } \\
\text { (Helsdon, Farley) }\end{array}$ & $\begin{array}{l}\text { 3-D, modified Clark-Hall, anelas- } \\
\text { tic } \\
\text { MPDATA advection of scalars }\end{array}$ & $\begin{array}{l}2 \text { liquid, } 3 \text { ice, predict } \mathrm{M} \\
\text { (Lin et al., 1983) } \\
\text { hail characteristics } \\
\text { no aerosols }\end{array}$ & $\begin{array}{l}120 \times 120 \times 20 \mathrm{~km}^{3} \\
1 \times 1 \times 0.25 \mathrm{~km}^{3} \text { resol. } \\
2 \text { s time step }\end{array}$ \\
\hline $\begin{array}{l}\text { DHARMA } \\
\text { (Fridlind, Ackerman) }\end{array}$ & $\begin{array}{l}\text { 3-D large eddy simulation anelas- } \\
\text { tic }\end{array}$ & $\begin{array}{l}\text { Sectional aerosols, } \\
\text { cloud liquid, and cloud ice } \\
\text { ( } 16 \text { bins each) } \\
\text { graupel characteristics }\end{array}$ & $\begin{array}{l}120 \times 120 \times 20 \mathrm{~km}^{3} \\
1 \times 1 \times 0.25 \mathrm{~km}^{3} \text { resol. } \\
0.2-5.0 \mathrm{~s} \mathrm{time} \mathrm{step}\end{array}$ \\
\hline $\begin{array}{l}\text { V. Spiridonov } \\
\text { (Spiridonov, Telenta) }\end{array}$ & $\begin{array}{l}\text { 3-D, Klemp-Wilhelmson dynam- } \\
\text { ics }\end{array}$ & $\begin{array}{l}2 \text { water, } 3 \text { ice, predict M } \\
\text { (modified Lin et al., 1983) } \\
\text { hail characteristics } \\
\text { no aerosols }\end{array}$ & $\begin{array}{l}140 \times 140 \times 15 \mathrm{~km}^{3} \\
1 \times 1 \times 0.5 \mathrm{~km}^{3} \text { resol. } \\
10 \mathrm{~s} \text { time step }\end{array}$ \\
\hline
\end{tabular}

$\mathrm{NO}_{2}, \mathrm{NO}, \mathrm{HNO}_{3}, \mathrm{H}_{2} \mathrm{O}_{2}$, methyl hydrogen peroxide $\left(\mathrm{CH}_{3} \mathrm{OOH}\right), \mathrm{CH}_{2} \mathrm{O}$, formic acid $(\mathrm{HCOOH})$, sulfur dioxide $\left(\mathrm{SO}_{2}\right)$, aerosol sulfate $\left(\mathrm{SO}_{4}\right)$, and ammonia $\left(\mathrm{NH}_{3}\right)$. Diurnally-varying, clear-sky photolysis rates are derived from the Troposphere Ultraviolet and Visible (TUV) radiation code (Madronich and Flocke, 1999). Dissolution of soluble species is assumed to be in Henry's Law equilibrium for low solubility species (e.g. CO) or is treated as diffusionlimited mass transfer for high solubility species (Barth et al., 2001). When cloud water or rain freezes, the dissolved species is retained in the frozen hydrometeor. Adsorption of gases onto ice or snow was not included in the simulation. The acidity of the cloud water and rain drops are calculated separately based on a charge balance. The chemical mechanism is solved with an Euler backward iterative approximation using a Gauss-Seidel method with variable iterations. A convergence criterion of $0.01 \%$ is used for all the species.
The production of $\mathrm{NO}_{\mathrm{x}}$ from lightning is the same as that in the UMd/GCE model (see Sect. 3.3) which follows DeCaria et al. (2005). The parameterization uses observed National Lightning Detection Network (NLDN) and lightning interferometer data to determine when a lightning flash occurs and whether that flash is a cloud-to-ground (CG) stroke or an intracloud (IC) stroke. Lightning NO is distributed vertically either as a Gaussian distribution peaking in the midtroposphere (CG flashes) or as a bimodal distribution peaking in the upper troposphere and mid-troposphere (IC flashes). The production of NO is 390 and 195 moles NO/flash for CG and IC flashes, respectively. At each model level, NO is divided equally among all grid cells within the $20 \mathrm{dBZ}$ region of the storm.

The model is configured to a $160 \times 160 \times 20 \mathrm{~km}^{3}$ domain with 161 grid points in each horizontal direction $(1 \mathrm{~km}$ resolution) and 51 grid points in the vertical direction with a variable resolution beginning at $50 \mathrm{~m}$ at the surface and stretching to $1200 \mathrm{~m}$ at the top of the domain. At the top of the model a rigid lid $(\mathrm{w}=0)$ is used; a damping layer at 
Table 2. Description of chemistry-related processes used by each model.

\begin{tabular}{|c|c|c|c|c|}
\hline Model & $\begin{array}{l}\text { Gaseous and aqueous } \\
\text { chemistry }\end{array}$ & Gas-aqueous transfer ${ }^{1}$ & $\begin{array}{l}\text { Chemistry- } \\
\text { microphysics }\end{array}$ & $\begin{array}{l}\text { Lightning production }{ }^{2} \text { of } \\
\mathrm{NO}_{\mathrm{x}} \text { (moles NO/flash) }\end{array}$ \\
\hline $\begin{array}{l}\text { WRF-AqChem } \\
\text { (Barth, Kim) }\end{array}$ & Online chem. & $\begin{array}{l}\text { Hybrid } \quad \mathrm{K}_{H} \text { and } \\
\text { diffusion-limited } \\
\text { mass transfer }\end{array}$ & $\begin{array}{l}\text { Retain species during } \\
\text { freezing }\end{array}$ & $\begin{array}{l}\text { DeCaria et al. (2005) } \\
\text { CG: } 390 \\
\text { IC: } 195\end{array}$ \\
\hline C. Wang & Online chem. & $\begin{array}{l}\text { Diffusion-limited } \\
\text { mass transfer }\end{array}$ & Retain & $\begin{array}{l}\text { Wang and Prinn (2000) } \\
\text { All: } 465\end{array}$ \\
\hline $\begin{array}{l}\text { U. Md/GCE } \\
\text { (Pickering, Ott, } \\
\text { Stenchikov) }\end{array}$ & Offline gas chem. & $\mathrm{K}_{H}$ & $\begin{array}{l}\text { Species removed by } \\
\text { liquid hydrometeors } \\
\text { only }\end{array}$ & $\begin{array}{l}\text { DeCaria et al. (2005) } \\
\text { CG: } 390 \\
\text { IC: } 195\end{array}$ \\
\hline $\begin{array}{l}\text { RAMS } \\
\text { (Leriche, Cautenet) }\end{array}$ & Online chem. & $\begin{array}{l}\text { Diffusion-limited } \\
\text { mass transfer }\end{array}$ & Degas & $\begin{array}{l}\text { Pickering et al. (1998) } \\
\text { CG: } 1113 \\
\text { IC: } 111\end{array}$ \\
\hline $\begin{array}{l}\text { Meso-NH } \\
\text { (Pinty, Barthe, Mari) }\end{array}$ & $\begin{array}{l}\text { Scav. of soluble } \\
\text { species }\end{array}$ & $\begin{array}{l}\text { Diffusion-limited } \\
\text { mass transfer }\end{array}$ & Degas & $\begin{array}{l}\text { Barthe et al. }(2005,2007) \\
\text { All: } 36\end{array}$ \\
\hline $\begin{array}{l}\text { SDSMT } \\
\text { (Helsdon, Farley) }\end{array}$ & Online gas chem. & None & None & $\begin{array}{l}\text { Helsdon et al. }(2001,2002) \\
\text { Range: 3-351 } \\
\text { Mean: } 97\end{array}$ \\
\hline $\begin{array}{l}\text { DHARMA }^{3} \\
\text { (Fridlind, Ackerman) }\end{array}$ & None & None & None & None \\
\hline $\begin{array}{l}\text { V. Spiridonov } \\
\text { (Spiridonv, Telenta) }\end{array}$ & $\begin{array}{l}\text { Tracers and aqueous } \\
\text { chem. }\end{array}$ & $\mathrm{K}_{H}$ & Retain & None \\
\hline
\end{tabular}

${ }^{1} \mathrm{~K}_{H}$ indicates that Henry's law equilibrium is used to partition between gaseous and aqueous phases.

2 CG is cloud-to-ground flashes; IC is intracloud flashes; All is both CG and IC flashes.

3 Tracers without chemical reactions are included in DHARMA so that comparisons are made with observed species such as $\mathrm{CO}_{\text {and }} \mathrm{O}_{3}$, which are less reactive for the integration time frame.

the top of the domain was not included. The simulation was integrated at a $10 \mathrm{~s}$ time step for all the described processes. To keep the convection near the center of the model domain, the grid is moved at $1.5 \mathrm{~m} \mathrm{~s}^{-1}$ eastward and $5.5 \mathrm{~m} \mathrm{~s}^{-1}$ southward.

\subsection{Wang's convective cloud model with chemistry} (C. Wang)

The convective cloud model of Wang and Chang (1993a) coupled with chemistry solves the 3 -D pseudo-elastic form of the continuity equation. The thermodynamic equations use an ice-liquid potential temperature as a conserved variable (Tripoli and Cotton, 1981). A $\delta$ four-stream radiation code $\mathrm{Fu}$ and $\mathrm{Liou}$ (1993), with predicted $\mathrm{O}_{3}$, water vapor, and liquid and ice phase hydrometeors, is used to compute the radiation transfer at both short and long waves (Wang and Prinn, 2000). We expect the effects of the radiation scheme on the storm simulation to be small for the $3 \mathrm{~h}$ integration. The advection of the chemical species including aerosols is calculated by using a revised Bott scheme (Bott, 1989, 1993) by Wang and Chang (1993a).

The cloud microphysics module predicts both number concentration and mass mixing ratios of cloud particles (e.g. a 2-moment scheme; Wang and Chang, 1993a). Two liquid and two ice phase hydrometeors are represented in the model version for this intercomparison. The precipitating ice hydrometeor has graupel-like characteristics. The aerosol module used for the current simulations has a prognostic CCN (hygroscopic) and IN (insoluble) calculation (Wang and Prinn, 2000). The CCN and IN calculations include transport, nucleation, and precipitation scavenging. The initial surface number concentration of $\mathrm{CCN}$ and IN is set to be $500 \mathrm{~cm}^{-3}$ and $100 \mathrm{~L}^{-1}$, respectively, and is assumed to be constant from the surface to the top of the model domain. Note that the actual cloud drop activation rate is determined by both the availability of aerosols and temperature as well as the supersaturation at the grid point (Wang, 2005a).

The chemistry sub-model predicts atmospheric concentrations of 25 gaseous and 8 aqueous chemical species (in both cloud droplets and raindrops and thus 16 prognostic variables), undergoing more than 100 reactions of $\mathrm{NO}_{\mathrm{x}}-\mathrm{HO}_{\mathrm{x}}-$ $\mathrm{O}_{3}-\mathrm{CO}-\mathrm{CH}_{4}-\mathrm{Sulfur}$ chemistry as well as transport and microphysical conversions (Wang and Chang, 1993a; Wang et al., 1998a; Wang and Prinn, 2000). Photolysis rates are calculated based on the solar flux determined by the radiation module. Dissolution of soluble species is parameterized via diffusion-limited mass transfer. When freezing of liquid 
hydrometeors occurs, the dissolved gases are assumed to be retained in the frozen hydrometeors. The chemistry mechanism is solved with the Livermore solver for ordinary differential equations (LSODE) (Hindmarsh, 1983; Wang et al., 1998a). A module of heterogeneous uptake by ice particles of several key chemical species including $\mathrm{O}_{3}, \mathrm{H}_{2} \mathrm{O}_{2}, \mathrm{HNO}_{3}$, $\mathrm{CH}_{2} \mathrm{O}, \mathrm{CH}_{3} \mathrm{OOH}, \mathrm{SO}_{2}$, and $\mathrm{H}_{2} \mathrm{SO}_{4}$ based on the first-order reaction approximation is also included (Wang, 2005b).

The production of $\mathrm{NO}_{\mathrm{x}}$ from lightning follows the disk model of Wang and Prinn (2000). The lightning rate is derived as a parameterization of actually predicted collision rate between ice crystals and graupel as well as dynamic variables by the model. A prescribed CG/IC ratio (not predicted by the parameterization) of 5\% is adopted based on the observation. NO production is set to be 465 moles NO per flash for both IC and CG flash. The freshly-produced NO molecules are distributed vertically based on either two (IC) normal distributions centered respectively at ice crystal and graupel concentrated layers or one (CG) such distribution centered at the latter layer, generally following DeCaria et al. (2000).

The model domain is $145 \times 120 \mathrm{~km}^{2}$ horizontally with a $1 \mathrm{~km}$ spatial resolution. The model domain extends from the surface to $20 \mathrm{~km}$ with a uniform grid spacing of $400 \mathrm{~m}$. At the top of the model a rigid lid (i.e. $\mathrm{w}=0$ ) is imposed with a $2.4 \mathrm{~km}$ sponge layer to absorb the reflection of gravity waves. The time step for the $3 \mathrm{~h}$ integration is $3 \mathrm{~s}$ for all the described processes.

\subsection{UMd/GCE (K. Pickering, L. Ott and G. Stenchikov)}

The UMd/GCE modeling system consists of the 3-D Goddard Cumulus Ensemble (GCE) model (Tao and Simpson, 1993; Tao et al., 2001) and the University of Maryland offline cloud-scale chemical transport model (CSCTM; DeCaria et al., 2005). The output of the GCE model is used to drive the CSCTM.

The GCE model hydrodynamics is based on a complete set of compressible, nonhydrostatic equations in a Cartesian coordinate system. A second order finite difference scheme in the vertical direction and the positive definite non-oscillatory horizontal advection scheme with small implicit diffusion (Smolarkiewicz, 1984; Smolarkiewicz and Grabowski, 1990) are employed. Newtonian damping is applied to the potential temperature and components of horizontal velocity at the top of the domain at about $25 \mathrm{~km}$. A parameterization of sub-grid turbulent mixing is based on the prognostic equation for turbulent kinetic energy (Deardorf, 1975; Klemp and Wilhelmson, 1978a, b; Soong and Ogura, 1980). Turbulent mixing is handled in the cloud model using a turbulent diffusion approximation.

To parameterize cloud microphysics a Kessler-type scheme (Kessler, 1969; Houze, 1993) for liquid hydrometeors (cloud water and rain) and the three-category scheme of Lin et al. (1983) for solid hydrometeors (ice, snow, and hail) are employed. The hydrometeors are assumed to be spherical with exponential size distributions except for cloud water and cloud ice, which are monodisperse. Hail characteristics are used for the simulation.

Output from the 3-D GCE model simulation is used to drive a 3-D Cloud-Scale Chemical Transport Model (CSCTM, DeCaria et al., 2005). Temperature, density, wind, hydrometeor (rain, snow, graupel/hail, cloud water, and cloud ice), and diffusion coefficient fields from the GCE model simulation are read into the CSCTM every ten minutes, and these fields are then interpolated to the model time step of $15 \mathrm{~s}$. The transport of chemical species is calculated using a van Leer advection scheme (Allen et al., 1991). Aerosols are not included in the simulation.

The CSCTM combines transport and lightning production with a chemical solver (SMVGEAR-II, Jacobson, 1995) and photochemical mechanism to simulate the chemical environment within the storm. The reaction scheme focuses on ozone photochemistry, containing the nonmethane hydrocarbons ethane, ethene, propane, and butane as described in DeCaria et al. (2000, 2005). The chemical scheme involves 35 active chemical species, 76 gas phase chemical reactions, and 18 photolytic reactions. Soluble species are removed from the gas phase by cloud and rain water with a dependence on Henry's Law coefficients. Uptake by ice is not included. Aqueous and multiphase reactions are not included. Photolysis rates are calculated as a function of time and are perturbed by the cloud, using typical summertime estimates from Madronich (1987) and cloud thickness taken from the GCE model output. Initial condition profiles of PAN, ethane, ethene, propane, and butane are from profiles constructed using observations from the 12 July STERAO storm by DeCaria et al. (2005). The single column "spin-up" version of the CSCTM is run for 15 min to allow the chemical concentrations to come into equilibrium before starting the simulation of the storm.

The lightning NO scheme in the CSCTM, described fully in DeCaria et al. (2005), is based on observed flash rate data. CG flash rates are calculated from NLDN observations and IC flash rates are determined by subtracting CG flash rates from total lightning flash rates obtained from interferometer observations. NO from CG flashes is distributed according to a Gaussian distribution peaking in the mid-troposphere while NO from IC flashes is distributed bimodally based on the typical vertical distributions of the VHF sources of IC and CG flashes from MacGorman and Rust (1998). NO from both types of flashes is also distributed vertically proportional to pressure. In each model layer, lightning NO is horizontally distributed uniformly to all grid cells with computed radar reflectivity greater than $20 \mathrm{dBZ}$. Production per CG flash (PCG), estimated to be 390 moles NO per flash, is based on the mean peak current of CG flashes observed by the NLDN and a relationship between peak current and energy dissipated (Price et al., 1997). An estimate of NO production per IC flash (PIC) is obtained by assuming various 
PIC/PCG ratios and comparing the results with anvil aircraft measurements. Assuming a PIC/PCG ratio of 0.5 produced a favorable comparison with observed in-cloud $\mathrm{NO}_{\mathrm{x}}$ mixing ratios and as a result, PIC is set to 195 moles NO per flash.

The UMd/GCE modeling system was integrated in a domain of $360 \times 328 \times 25 \mathrm{~km}^{3}$ in the $\mathrm{x}, \mathrm{y}$ and $\mathrm{z}$ directions, respectively. The horizontal grid spacing was $2 \mathrm{~km}$ in both horizontal directions, and $0.5 \mathrm{~km}$ in the vertical. The GCE meteorology model was integrated using a $3 \mathrm{~s}$ time step to maintain numerically stability. The chemistry transport model is updated with a $30 \mathrm{~s}$ time step (though SMVGEAR-II itself uses a smaller time step based on stiffness).

\subsection{RAMS (M. Leriche and S. Cautenet)}

Gas and aqueous chemistry have been incorporated into the Regional Atmospheric Modeling System (RAMS) version 4.3 (Cotton et al., 2003). The basic equations in RAMS for solving the dynamical and thermodynamical variables are non-hydrostatic time-split compressible. The predicted variables are advanced in time via a hybrid leapfrog (on long time step) forward-backward (on short time step), 2nd order flux conservative form (Tripoli and Cotton, 1982). Transported scalars include hydrometeors and chemical species. Aerosols are not simulated for this case.

The cloud microphysics module predicts both number concentration and mass mixing ratios of cloud particles, i.e. a two-moment bulk scheme (Meyers et al., 1997), using gamma distributions to represent the hydrometeor size distributions. For the simulation performed here, the water categories include cloud and rain drops and three ice condensate species: pristine ice, snow, and hail.

The chemistry module includes both gas and aqueous phase chemistry. For gas-phase chemistry, the mechanism includes 29 species with 65 reactions that represent the reactivity of ozone, $\mathrm{NO}_{\mathrm{y}}$ and $\mathrm{VOC}$ including isoprene chemistry (Arteta et al., 2006; Taghavi et al., 2004). For aqueous-phase chemistry, the mechanism includes 10 species with 18 reactions that represent the $\mathrm{HO}_{\mathrm{x}}$ chemistry and the formation of nitrate, sulfate and formic acid (Audiffren et al., 1998). For the exchange of chemical species between gas phase and liquid hydrometeors, the mass transfer kinetic formulation of Schwartz (1986) is used taking into account the possible deviation from Henry's law equilibrium. The Quasi-Steady State Approximation (QSSA) is used as the chemical solver. The redistribution of chemical species by microphysical processes is only considered for liquid hydrometeors. Therefore, when freezing of liquid water occurs, the dissolved species are degassed. The interactions of chemical species with ice phase are not yet implemented in the model.

The lightning- $\mathrm{NO}_{\mathrm{x}}$ parameterization is based on Pickering et al. (1998). The parameterization consists of four parts: flash rate, flash type, flash location and NO production rate. The flash rate is computed from the maximum vertical velocity using a power law. The fractions of intracloud (IC) and cloud to ground (CG) flash are computed by estimating the depth of the layer from the freezing level (the $0^{\circ} \mathrm{C}$ isotherm in the cloud) to the cloud top. For this storm, the calculation gives $\sim 4 \%$ CG fraction, which is consistent with observations. The CG flashes are placed within the $20 \mathrm{dBZ}$ region from the surface to the model-calculated $-15^{\circ} \mathrm{C}$ isotherm and the IC flashes within the $20 \mathrm{dBZ}$ region of the cloud above the $-15^{\circ} \mathrm{C}$ isotherm. The NO production rate is 1113 and 111 moles NO per each CG and IC flash, respectively.

For the simulation of the STERAO storm, two nesting grids are used, the large one of $240 \times 240 \times 20 \mathrm{~km}^{3}$ with a horizontal resolution of $3 \mathrm{~km}$ and the small one of $120 \times 120 \times 20 \mathrm{~km}^{3}$ with a horizontal resolution of $1 \mathrm{~km}$. The domain has 50 vertical levels with resolution stretching from $50 \mathrm{~m}$ at the surface to $1000 \mathrm{~m}$ at the top of the domain. A rigid lid $(\mathrm{w}=0)$ upper boundary condition is used. The small grid moves into the large one with a constant velocity of $1.5 \mathrm{~m} \mathrm{~s}^{-1}$ towards the east and $5.5 \mathrm{~m} \mathrm{~s}^{-1}$ southward. A $5 \mathrm{~s}$ time step is used.

\subsection{Meso-NH (J.-P. Pinty, C. Barthe and C. Mari)}

The Meso-NH model (Lafore et al., 1998) is a complete meteorological model that contains a flexible chemical scheme, an aerosol scheme, a 1- or 2-moment microphysical scheme and an electrical scheme. The model integrates an anelastic system of equations. The Multidimensional Positive Definite Advection Transport Algorithm (MPDATA; Smolarkiewicz and Grobowski, 1990) is used for the advection scheme, and turbulence is parameterized with a 3-D scheme. Transported scalars include hydrometeors, chemical species and electrical charge. Aerosols are not included in this simulation.

The cloud microphysics is described by a mixed-phase scheme (Pinty and Jabouille, 1998) that takes into account 6 water variables (water vapor, cloud droplets, raindrops, pristine ice, snow and graupel). For this study, graupel-like characteristics are used. Only mass mixing ratios of these microphysical species are predicted.

For these simulations, no chemical reactions are considered in the gas and aqueous phases. The partitioning between gas and liquid phases is calculated for the soluble gases, $\mathrm{CH}_{2} \mathrm{O}, \mathrm{H}_{2} \mathrm{O}_{2}$, and $\mathrm{HNO}_{3}$, following the mass transfer kinetic formalism of Schwartz (1986). The scavenged gases are tracked in the cloud droplets and in the rain drops only, but not in the ice phase. Note that the liquid drops do get transported to the glaciated regions of the modeled storm. $\mathrm{CO}$ and $\mathrm{O}_{3}$ are insoluble. $\mathrm{NO}_{\mathrm{x}}$ is represented by 2 variables: the first one corresponds to the background $\mathrm{NO}_{\mathrm{x}}$ and the second one includes both background and the $\mathrm{NO}_{\mathrm{x}}$ produced from lightning.

Meso-NH also contains an explicit electrification and lightning flash scheme (Barthe et al., 2005). The electric charges are carried by each of the hydrometeor categories and are separated via non-inductive processes (i.e., icegraupel collisions). Lightning flashes are triggered when the 
ambient electric field exceeds a threshold $\left(167 \rho(\mathrm{z}) \mathrm{kV} \mathrm{m}^{-1}\right)$. The lightning flashes produce both bi-directional leaders and branch streamers (Barthe et al., 2005). Nitrogen oxides are added along the lightning flash path as a function of the pressure and the channel length as suggested by Wang et al. (1998b) from laboratory experiments (Barthe et al., 2007). The production of NO is 36 moles NO per flash for both CG and IC flashes.

The simulation is configured to that described by Skamarock et al. (2000). The computational domain is $160 \times 160 \times 50$ grid points with a horizontal resolution of $1 \mathrm{~km}$ and a vertical spacing ranging from $75 \mathrm{~m}$ at the ground to $700 \mathrm{~m}$ in the stratosphere. A gravity wave damping layer is placed between the model top and $15 \mathrm{~km}$ height. The time step $(2 \mathrm{~s})$ is used for all the described processes.

\subsection{SDMST (J. Helsdon and R. Farley)}

The 3-D SEM (Storm Electrification Model) has fully coupled microphysical, electrical and chemical processes. The model is a modified form of the 3-D nested grid model developed by Terry Clark and associates (Clark, 1977, 1979; Clark and Farley, 1984; Clark and Hall, 1991). The model is nonhydrostatic and uses the anelastic approximation to eliminate sound waves. For the dynamics, the model employs the flux form of the second-order operators of Arakawa (1966) for the spatial derivatives, and treats time derivatives using a second-order leapfrog scheme. This formulation allows the model to conserve kinetic energy. Advection of scalar quantities uses the multidimensional positive-definite advection transport algorithm (MPDATA) developed by Smolarkiewicz (1984) and Smolarkiewicz and Clark (1986). Subgrid-scale turbulence is parameterized according to first-order theory.

The model employs the single moment (mixing ratio) microphysical parameterization scheme of Lin et al. (1983) which allows five hydrometeor classes; cloud water, rain, cloud ice, snow, and graupel/hail. For the simulation reported here, the model uses parameters characteristic of hail to represent the graupel/hail field.

Gas phase chemical processes are included in the model as described in Zhang et al. (2003). This formulation has 18 reactions involving nine tracked chemical species including $\mathrm{NO}, \mathrm{NO}_{2}, \mathrm{O}_{3}, \mathrm{CH}_{4}, \mathrm{CO}, \mathrm{OH}$ and $\mathrm{HO}_{2}$, with $\mathrm{HNO}_{3}$ as a sink. The chemistry solver is a modified QSSA solver. The resulting equation set is solved using a 2nd order Runge-Kutta scheme with the time step controlled by the stiffness of the chemistry equations.

The treatment of electrical processes follows Helsdon and Farley (1987) and Helsdon et al. (2001). Each hydrometeor class has an associated charge density in addition to the positive and negative small ion concentrations that combine to form the total charge density, which is related to the electrical potential through Poisson's equation. The simulation includes an explicit prediction of intracloud lightning discharges as described in Helsdon et al. (1992) and Hels- don et al. (2002). A lightning channel is initiated when and where a threshold electric field is attained $\left(225 \mathrm{kV} \mathrm{m}^{-1}\right.$ in this case) and propagates bi-directionally away from the initiation point following the electric field vector. The channel terminates when the electric field at the ends of the propagating channel drops below a preset value $\left(75 \mathrm{kV} \mathrm{m}^{-1}\right)$. Once the channel is formed, its linear charge density is calculated from theory and converted into an equivalent small ion density. The charged channel modifies the electric field and consequently modifies the electric energy in the domain in a physically consistent manner. By calculating the electrical energy just before and immediately after the discharge, the energy dissipation can be determined. NO production $\left(9 \times 10^{16} \mathrm{NO}\right.$ molecules $\mathrm{J}^{-1}$ at sea level) is proportional to this electrical energy change and pressure, and is limited to the immediate vicinity of the lightning channel. For this simulation, the NO production ranges from 5 to 351 moles NO per flash with a mean of 97 .

The simulation is configured to a $120 \times 120 \times 20 \mathrm{~km}^{3}$ domain using $1 \mathrm{~km}$ horizontal grid spacing and $250 \mathrm{~m}$ vertical resolution. At the top of the model, a 4-km deep Rayleigh friction upper level absorber for the velocity components and potential temperature is used. The model integrations proceed using a $2 \mathrm{~s}$ time step. A Galilean transformation is applied to keep the main convection within the interior regions of the domain. For the 10 July STERAO case the grid translates to the east at $4 \mathrm{~m} \mathrm{~s}^{-1}$ and to the south at $5 \mathrm{~m} \mathrm{~s}^{-1}$.

\subsection{DHARMA (A. Fridlind and A. Ackerman)}

The DHARMA (Distributed Hydrodynamic AerosolRadiation-Microphysics Application) model treats atmospheric and cloud dynamics with a large-eddy simulation code (Stevens and Bretherton, 1996) that solves an anelastic approximation of the Navier-Stokes equations appropriate for deep convection (Lipps and Hemler, 1986).

Embedded within the dynamics code, DHARMA treats aerosol and cloud microphysics with the CARMA (Community Aerosol-Radiation Model for Atmospheres) code (Ackerman et al., 1995; Jensen et al., 1998). Aerosols, water drops, ice crystals, and solute within the drops and crystals are tracked in a range of sizes (16 size categories each). The aerosols are assumed to be ammonium bisulfate distributed log-normally (dry size). The initial concentration and size distribution parameters of the aerosol are listed in Table 3 and are based on the condensation nuclei measurements on the aircraft. The density of ice is a function of size, roughly representative of conical graupel. Microphysical processes include aerosol activation into drops, condensational growth and evaporation of drops, gravitational collection, spontaneous and collision-induced drop breakup, homogeneous and heterogeneous freezing of aerosols and drops, depositional growth and sublimation of ice, sedimentation of liquid and ice, melting, and Hallett-Mossop rime splintering. The 
microphysics treatment is identical to that used by Fridlind et al. (2004), where further detail is provided.

The DHARMA model transports aerosols, hydrometeors, and trace gases. Chemistry and production of $\mathrm{NO}_{\mathrm{x}}$ from lightning are not included in the model.

Results shown here are for uniform $1 \mathrm{~km}$ horizontal resolution and $250 \mathrm{~m}$ vertical resolution over a $120 \times 120 \times 20 \mathrm{~km}^{3}$ domain, which is nudged to the initial profile along each face. The boundary condition at the top of the model is a rigid lid $(\mathrm{w}=0)$. Dynamics and gravitational collection are advanced with a $5 \mathrm{~s}$ time step; all other microphysical processes are advanced with a time step of 0.2 to $5 \mathrm{~s}$ that is chosen based on the processes that are active in each grid cell as the simulation progresses.

3.8 V. Spiridonov's convective cloud model with chemistry (V. Spiridonov and B. Telenta)

The model (Spiridonov and Curic, 2003, 2005) is a threedimensional, non-hydrostatic, time-dependant, compressible system using the dynamic and thermodynamics schemes from Klemp and Wilhelmson (1978a) and the bulk cloud microphysics scheme from Lin et al. (1983) that takes into account 6 water variables (water vapor, cloud droplets, ice crystals, rain, snow, and graupel). The graupel hydrometeor class is represented as hail with a density of $0.9 \mathrm{~g} \mathrm{~cm}^{-3}$. While the mass of aerosol sulfate is predicted, the aerosols do not affect the cloud drop activation. The chemistry module includes 4 species $\left(\mathrm{SO}_{2}, \mathrm{SO}_{4}^{2-}, \mathrm{NH}_{4}^{+}, \mathrm{H}_{2} \mathrm{O}_{2}\right)$ and 3 aqueous-phase reactions describing in-cloud sulfate chemistry (Taylor, 1989). The absorption of chemical species from the gas phase into cloud water and rainwater is determined by either Henry's law equilibrium (Taylor, 1989), or by diffusion-limited mass transfer between gas and liquid phases to include possible non-equilibrium states, (Barth et al., 2001). All equilibrium constants and oxidation reactions are temperature dependent according to the van't-Hoff relation (Seinfeld, 1986). Cloud water and rainwater $\mathrm{pH}$ is calculated using the charge balance equation from Taylor (1989). The model includes a freezing transport mechanism of chemical species based on Rutledge et al. (1986). Thus, when water from one hydrometeor class is transferred to another, the dissolved scalar is transferred to the destination hydrometeor in proportion to the water mass that was transferred. Production of NO from lightning is not parameterized in the Spiridonov model.

For the intercomparison simulation, the model is configured to a domain of $140 \times 140 \times 15 \mathrm{~km}^{3}$ with $1 \mathrm{~km}$ horizontal resolution and $500 \mathrm{~m}$ vertical resolution. A rigid lid $(\mathrm{w}=0)$ is used for the top boundary condition. A $10 \mathrm{~s}$ time step is used for all the described processes.
Table 3. Aerosol parameters used for initialization in the DHARMA model.

\begin{tabular}{cccc}
\hline $\begin{array}{c}\text { Height } \\
(\mathrm{m}, \mathrm{m} . \mathrm{s} .1 .)\end{array}$ & $\begin{array}{c}\mathrm{N}_{\text {tot }} \\
\left(\mathrm{cm}^{-3}\right)\end{array}$ & $\begin{array}{c}\sigma \\
\text { (dimensionless) }\end{array}$ & $\begin{array}{c}r_{g} \\
(\mu \mathrm{m})\end{array}$ \\
\hline 1500 & 6609 & 2.0 & 0.05 \\
2700 & 4388 & 2.0 & 0.05 \\
4000 & 409 & 1.5 & 0.01 \\
5000 & 195 & 1.5 & 0.01 \\
6000 & 108 & 1.5 & 0.01 \\
6500 & 128 & 1.5 & 0.01 \\
26500 & 128 & 1.5 & 0.01 \\
\hline
\end{tabular}

$\mathrm{N}_{\text {tot }}$ is the total concentration, $\sigma$ is the geometric standard deviation, and $r_{g}$ is the geometric mean radius of the aerosol size distribution.

\section{Results}

Four types of model results are presented. First, the storm intensity and structure are analyzed by intercomparison of peak vertical velocity and radar reflectivity with observations. Second, the redistribution of $\mathrm{CO}, \mathrm{O}_{3}$ and $\mathrm{NO}_{\mathrm{x}}$ are presented, and anvil mixing ratios are compared with analyzed UND Citation aircraft measurements. Then the flux of air, $\mathrm{CO}$ and $\mathrm{NO}_{\mathrm{x}}$ through a plane across the anvil is compared to that determined from the observations. Lastly the mixing ratios of $\mathrm{CH}_{2} \mathrm{O}, \mathrm{H}_{2} \mathrm{O}_{2}$, and $\mathrm{HNO}_{3}$ in the anvil are compared among models.

\subsection{Storm intensity and structure}

The maximum vertical velocity in the model domain was recorded at 10-min intervals (Fig. 2). Each model shows a rapid increase in peak updraft velocity at the beginning of the simulation. Most simulations maintain peak updrafts above $24 \mathrm{~m} \mathrm{~s}^{-1}$ during the remainder of the simulation, while radar observations show peak updrafts to be between 24 and $38 \mathrm{~m} \mathrm{~s}^{-1}$. Transitions to updraft velocities of $35 \mathrm{~m} \mathrm{~s}^{-1}$ or more are seen by C. Wang's model, WRFAqchem, DHARMA, and Meso-NH. The height of the peak updraft ranges from $7 \mathrm{~km}$ to $14 \mathrm{~km}$ m.s.l., which is similar but somewhat higher than observations.

The storm structure can be evaluated by comparing the modeled radar reflectivity to the observed radar reflectivity. Both horizontal and vertical cross-sections of radar reflectivity are examined. At 23:12 UTC 10 July, the CSU CHILL radar reflectivity at $\mathrm{z}=10.5 \mathrm{~km}$ m.s.l. indicates two convective cores oriented in a northwest-southeast line with an anvil spreading to the east-southeast (Fig. 3). However, during the multicell stage of the storm 2 to 4 convective cells were observed. After $1 \mathrm{~h}$ of simulation, the results from the models have 2-3 convective cores oriented northwest-southeast which is in line with the observations. The magnitude of the reflectivity differs among models due to 1 ) whether graupel 

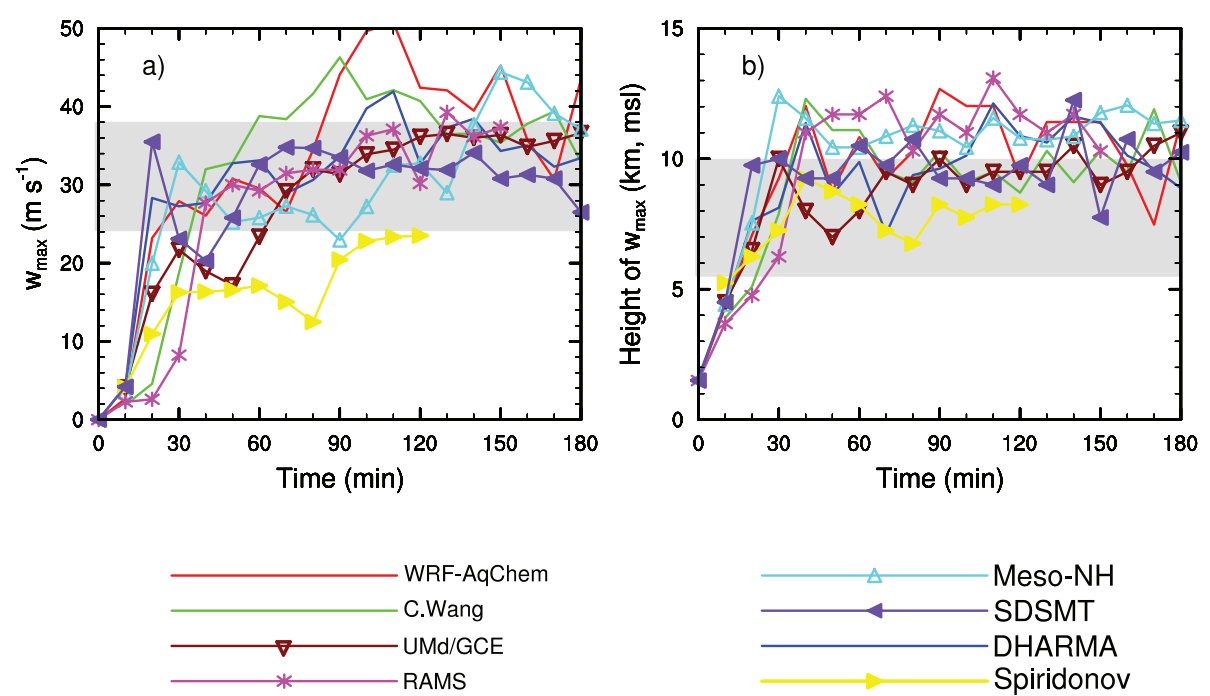

Fig. 2. (a) Peak updraft speed and (b) height of peak updraft from each of the simulations. Gray shaded regions represent observed values derived from the CHILL radar (W. Deierling, personal communication).

characteristics (C. Wang, Meso-NH, DHARMA models) or hail characteristics are modeled, 2) model resolution, and 3) single-moment versus multi-moment (C. Wang, DHARMA, RAMS models) microphysics parameterizations. The width of the anvil varies among models. The observed reflectivity has an anvil width of 32-40 km at 23:12 UTC, while model results range from $12.5 \mathrm{~km}$ to $45 \mathrm{~km}$. Seifert and Weisman (2005) noted that double-moment microphysics parameterizations tend to produce broader anvils than single-moment microphysics parameterizations. The results from our study do not distinctly show this correlation. While C. Wang's model with double-moment microphysics has a widespread anvil, DHARMA and RAMS have anvils similar in width to the models with single-moment microphysics. Other factors contributing to the anvil width are the graupel or hail characteristics used (which influences the particle's fall speed), the dynamics formulation, the vertical or horizontal resolution, and the number of bubbles used to initiate the convection. For example, a sensitivity simulation with a 2-bubble initiation performed by WRF-Aqchem found that the anvil was less extensive in both the length and width than the 3-bubble initiation used in the intercomparison exercise.

The vertical cross section of observed reflectivity along the storm axis (Fig. 4) shows that the northwest core (left side of figure) is decaying while the southeast core is reaching its mature stage. During the multicell stage of the storm, radar reflectivity plots show 2 to 4 convective cores being active at any given time. All of the models show 3 convective cores, with all cores of approximately the same reflectivity magnitude except for the Meso-NH model. The Meso-NH model has weaker reflectivity most likely because of the graupel (rather than hail) characteristics used in their microphysics parameterization. While the reflectivity in the observed anvil is weak (5-20 dBZ) and somewhat extensive ( $>35 \mathrm{~km}$ from the southeast core to the anvil edge), the simulated anvils are stronger (5-35 dBZ) and less extensive (15-25 km from the southeast core to the anvil edge). The maximum height of the modeled reflectivity varies among models. The reflectivity simulated by Spiridonov only reaches $11.5 \mathrm{~km}$, m.s.l., while the reflectivity simulated by the $\mathrm{C}$. Wang and RAMS models reach $16.5 \mathrm{~km}$, m.s.l. Observations show the reflectivity top to be 14.5 to $16.5 \mathrm{~km}$, m.s.l.

In summary, the discrepancies among models for radar reflectivity, which are mainly due to the differences between the treatments of cloud microphysics, highlight the response of different cloud models to the same initiation protocol and the challenge of modeling the realistic structure of clouds even using cloud resolving models. Nevertheless, the modeled cloud structures are all reasonably simulated. Thus, it is possible to use these models to simulate trace gas transport as part of the intercomparison.

\subsection{Distributions of $\mathrm{CO}, \mathrm{O}_{3}$, and $\mathrm{NO}_{\mathrm{x}}$}

Mixing ratios of gas-phase $\mathrm{CO}, \mathrm{O}_{3}$, and $\mathrm{NO}_{\mathrm{x}}$ are compared to observations using two approaches. First, model results are evaluated with aircraft measurements which were obtained from the University of North Dakota (UND) Citation aircraft as it flew across the anvil. Second, cross-sections of the gasphase mixing ratios are compared to a derived cross-section obtained from several transects of the anvil by the aircraft.

The UND Citation aircraft sampled the outflow region of the storm by performing across-anvil transects at different levels in the anvil (transects indicated in Fig. 3). Two transects are used to compare model results with observations. The first transect is $10 \mathrm{~km}$ downwind of the southeasternmost convective cell at 23:10 UTC (which corresponds to 

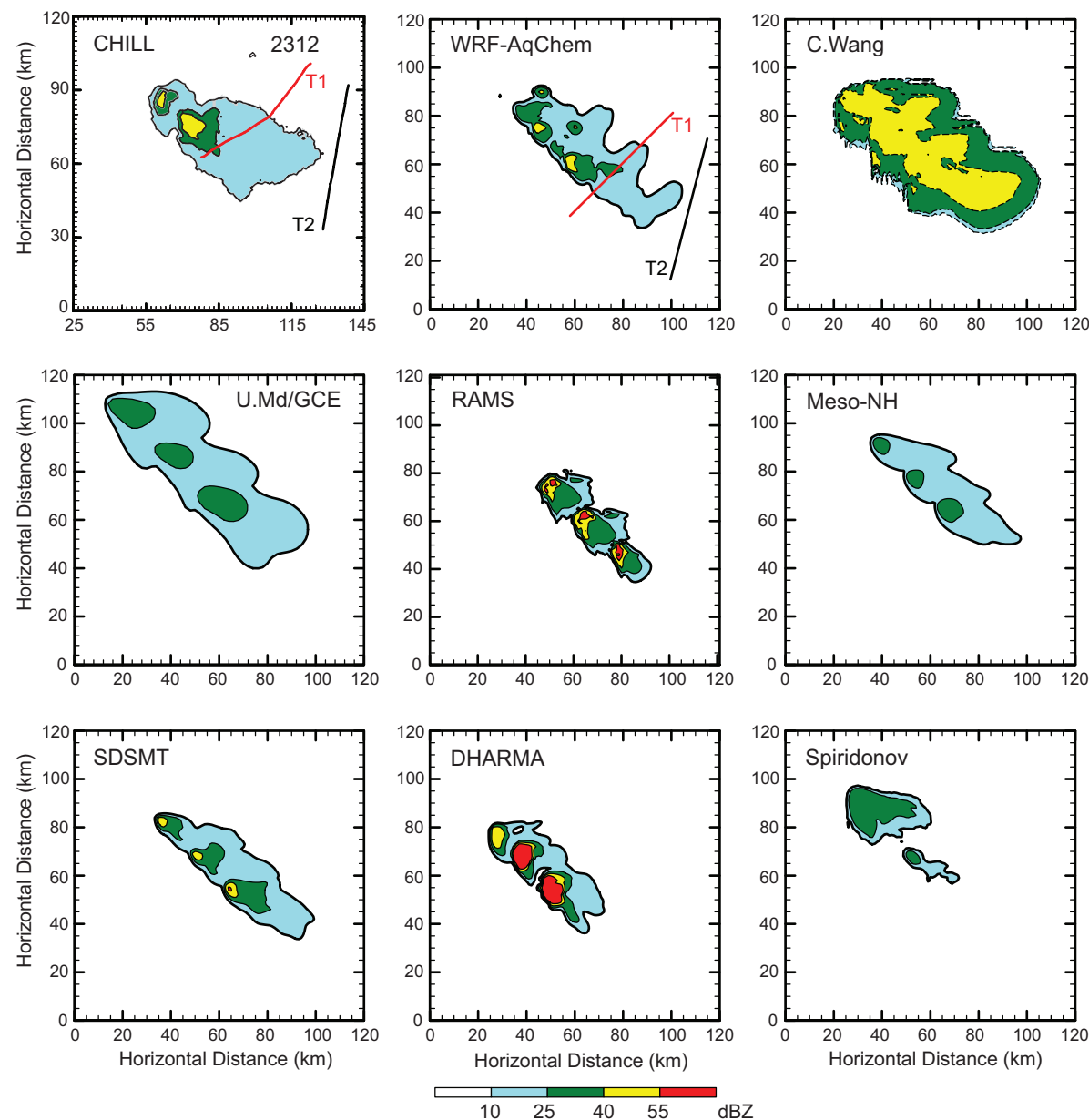

Fig. 3. Radar reflectivity (dBZ) at $z=10.5 \mathrm{~km}$ m.s.l. Observations (upper left panel) from CSU CHILL radar at 23:12 UTC. Model results at $t=1 \mathrm{~h}$ from WRF-AqChem, C. Wang, UMd/GCE, RAMS, Meso-NH, SDSMT, DHARMA, and Spiridonov models. T1 and T2 lines in the CHILL panel represent the actual flight track for the two transects shown in subsequent figures. T1 and T2 lines in the WRF-AqChem panel represent the location of the modeled transects shown in the same subsequent figures.

$t=1 \mathrm{~h}$ in the simulations) at $11.6 \mathrm{~km}$ m.s.l. The second transect is $\sim 50 \mathrm{~km}$ downwind of the southeastern-most convective cell at 2335 UTC (corresponding to $t=1 \mathrm{~h} 30 \mathrm{~min}$ in the simulations) at $11.2 \mathrm{~km} \mathrm{m.s.1.} \mathrm{One} \mathrm{would} \mathrm{expect} \mathrm{that} \mathrm{the}$ model results discussed below are dependent on the chosen location of transect. The horizontal variability of a species in the anvil can be fairly large (Barth et al., 2007) as the storm dynamics and entrainment can vary with time. The choice of the location for the across-anvil transect in each model is that which is most appropriate at the $\sim 10 \mathrm{~km}$ and $\sim 50 \mathrm{~km}$ downwind location to compare to the available observations.

Mixing ratios of gas-phase $\mathrm{CO}$ in the anvil are observed to be enhanced compared to the background upper troposphere (Fig. 5) because convective transport moves high mixing ratios from the boundary layer to the upper troposphere. Conversely, gas-phase $\mathrm{O}_{3}$ mixing ratios are lower in the anvil than in the upper troposphere because relatively-low $\mathrm{O}_{3}$ mixing ratios are transported from the boundary layer.
The model simulations predict these enhancements and depletions of $\mathrm{CO}$ and $\mathrm{O}_{3}$ mixing ratios, which agree with the observations (Fig. 5), especially in the core of the anvil. All models underpredict the $\mathrm{O}_{3}$ mixing ratio on the southwest edge of the anvil, a feature that may be attributed to mixing of stratospheric air. The results from the models can be sensitive to the time and location of the transect. For example, the horizontal distribution of $\mathrm{CO}$ at $\mathrm{z}=11.5 \mathrm{~km}$ shown in Barth et al. (2007) illustrates heterogeneity as CO is entrained/detrained during transport from the boundary layer to the anvil. Keeping these sensitivities in mind, the model results are within $10-15 \%$ of the observations in the anvil.

Observed gas-phase NO mixing ratios (Fig. 6) are strongly enhanced within the anvil compared to the background upper troposphere primarily due to lightning production of NO. Modeled gas-phase $\mathrm{NO}_{\mathrm{x}}$ mixing ratios show the importance of the lightning source. The DHARMA and Spiridonov models do not include production of $\mathrm{NO}_{\mathrm{x}}$ from lightning 

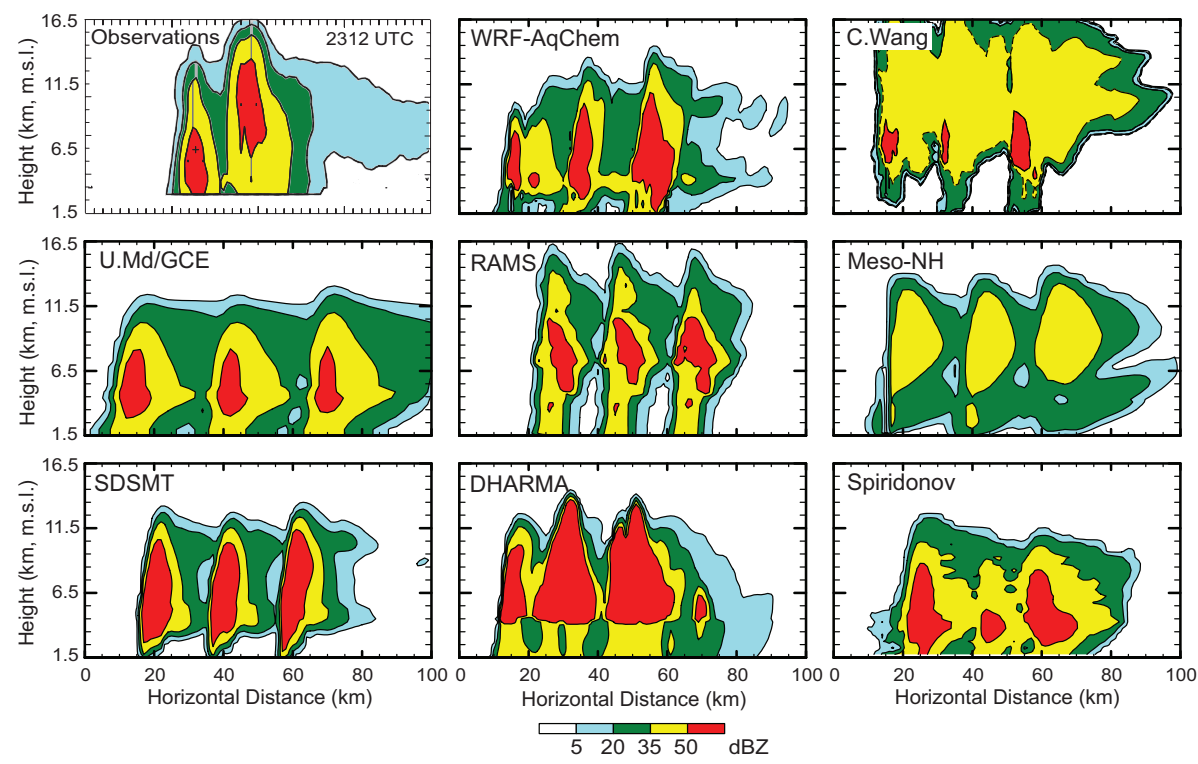

$5 \quad 203550 \quad d B Z$

Fig. 4. Radar reflectivity (dBZ) along the NW-SE vertical cross-section. Observations (upper left panel) from CSU CHILL radar at 23:12 UTC. Model results at $t=1 \mathrm{~h}$ from WRF-AqChem, C. Wang, UMd./GCE, RAMS, Meso-NH, SDSMT, DHARMA and Spiridonov models.

and therefore substantially underpredict the $\mathrm{NO}_{\mathrm{x}}$ mixing ratios. The increase in $\mathrm{NO}_{\mathrm{x}}$ seen within the anvil region for the DHARMA and Spiridonov models is a result of transport of boundary layer $\mathrm{NO}_{\mathrm{x}}$ to the upper troposphere. The other models, which include lightning-produced $\mathrm{NO}_{\mathrm{x}}$, generally show $\mathrm{NO}_{x}$ mixing ratios elevated compared to the DHARMA and Spiridonov models within the anvil. For the first transect, WRF-AqChem, C. Wang, Meso-NH, and SDSMT $\mathrm{NO}_{x}$ mixing ratios are similar to the observations, but for shorter across-anvil distances. Only the Meso-NH model has a similar area under the curve as the observations, indicating the total amount of $\mathrm{NO}_{\mathrm{x}}$ placed into the $11.6 \mathrm{~km}$ m.s.l. height is realistic (note that mass fluxes of $\mathrm{NO}_{\mathrm{x}}$ integrated over the across-anvil area and over time are discussed in the next section). For the second transect, all of the models that include $\mathrm{NO}_{\mathrm{x}}$ production by lightning agree reasonably well with observations. The results from the RAMS model are generally lower than the other models with a lightning$\mathrm{NO}_{\mathrm{x}}$ production scheme. The details of the RAMS lightning$\mathrm{NO}_{\mathrm{x}}$ parameterization (Pickering et al., 1998) indicate that small amounts of NO (111 moles NO/IC flash) are produced and placed in a large volume (above $-15^{\circ} \mathrm{C}$ isotherm for cloud regions $>20 \mathrm{dBZ}$ (Fig. 4)) leading to a reduced $\mathrm{NO}_{\mathrm{x}}$ mixing ratio. The UMd/GCE model produces more NO per IC flash (195 moles/flash) but concentrations are reduced because of the large volume of cloud $>20 \mathrm{dBZ}$ (Fig. 4). In addition, variations from the models can be a result of the location and time of the model transect as is discussed above with the $\mathrm{CO}$ transect. This is the first time simulated lightning $\mathrm{NO}_{\mathrm{x}}$ production from a specific model transect has been directly compared with observations from the corresponding specific aircraft transect of a storm anvil. To obtain $\mathrm{NO}_{\mathrm{x}}$ mixing ratios similar in magnitude to observations is encouraging. These results highlight that several key parameters (lightning flash rate which depends on the storm kinematic and microphysical characteristics, lightning type, NO source location, NO production per lightning flash) need to be incorporated in lightning- $\mathrm{NO}_{\mathrm{x}}$ parameterizations, and that these same parameters play an important role in contributing to uncertainties in $\mathrm{NO}_{\mathrm{x}}$ mixing ratios in convective outflow.

Skamarock et al. (2003) analyzed the UND Citation aircraft data taken across the anvil of the storm. The Citation aircraft mapped out the anvil structure during $\sim 1 \mathrm{~h} 30 \mathrm{~min}$ time period by traversing the anvil in horizontal passes, approximately perpendicular to the long axis of the anvil, at elevations starting at approximately $11.8 \mathrm{~km}$ m.s.l. (close to the anvil top) and ending at approximately $6.8 \mathrm{~km} \mathrm{~m} . \mathrm{s} .1$. Skamarock et al. (2003) projected the cloud particle concentration, $\mathrm{CO}, \mathrm{O}_{3}$, and $\mathrm{NO}$ observations onto a vertical plane using an objective analysis procedure. Uncertainties related to this methodology are associated with the temporal evolution of the storm while the measurements were taken and with the background state of each constituent measured. Skamarock et al. (2003) conclude that these uncertainties are fairly small resulting in a reasonable flux analysis. Model predictions of these variables taken along a similar plane (similar to the $\mathrm{T} 2$ cross-section shown for WRF-AqChem in Fig. 3) can then be compared to the analyzed observations.

Vertical cross-sections across the anvil of ice particle concentration are shown in Fig. 7. The analyzed observations are for ice $>25 \mu \mathrm{m}$ diameter $\left(D_{\text {ice }}\right)$ based on the measurements from the Particle Measuring Systems 2-D probe (Dye et al., 

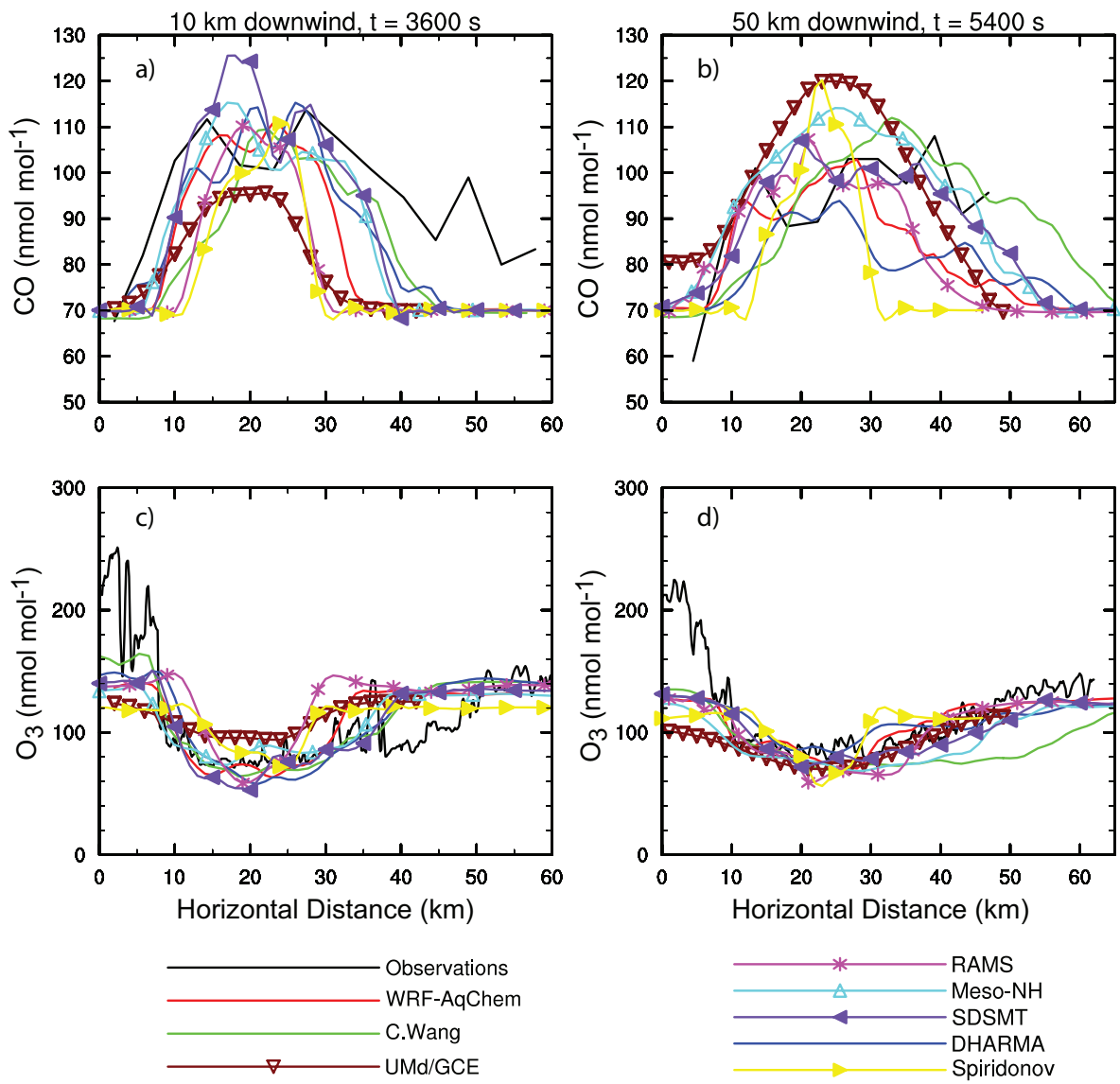

Fig. 5. $\mathrm{CO}$ and $\mathrm{O}_{3}$ measurements (black lines) from the UND-Citation aircraft for across-anvil transects at $10 \mathrm{~km}$ downwind of the south-easternmost convective cell and $11.6 \mathrm{~km}$ m.s.l. (left panels) and at $50 \mathrm{~km}$ downwind of the south-easternmost convective cell and $11.2 \mathrm{~km}$ m.s.l. (right panels). Results from model calculations are plotted along these transects.

2000). The results from the models tend to match or overpredict the observations. The results from the C. Wang and RAMS models are only for $D_{\text {ice }}>25 \mu \mathrm{m}$ giving good agreement with observations. While the DHARMA results are also only for ice with $D_{\text {ice }}>25 \mu \mathrm{m}$, the results overpredict the ice particle number, suggesting other factors contribute to increased predicted ice particle number. Using graupel characteristics instead of hail can also increase ice concentrations in the anvil region because graupel has a smaller fall speed and therefore is carried further into the anvil. The models that predicted only the mass of the cloud particles (WRFAqChem, UMd/GCE, Meso-NH, SDSMT, Spiridonov) assumed a diameter for the ice hydrometeor category (for example, WRF-AqChem set $D_{\text {ice }}=45 \mu \mathrm{m}$ ) for the purposes of estimating the number concentration. The calculation of number concentration is very dependent on the assumed ice diameter since the anvil is primarily composed of small ice particles.

Gas-phase CO analyzed from the observations (Fig. 8) reach $110 \mathrm{nmol} \mathrm{mol}^{-1}$ or so in the anvil. Simulated CO mixing ratios also reach those values in the anvil. There is a slight underprediction of CO seen in the WRF-AqChem model. In general, the models reasonably simulate $\mathrm{CO}$ mixing ratios in the anvil.

Vertical cross-sections of observed $\mathrm{O}_{3}$ (Fig. 9) show $\mathrm{O}_{3}$ being depleted in the anvil to values of about $80-100 \mathrm{nmol} \mathrm{mol}^{-1}$, but also show a small region of downward-intruding, high $\left(>300 \mathrm{nmol} \mathrm{mol}^{-1}\right) \mathrm{O}_{3}$ at the top of the anvil on the SSW edge (upper left part of figure). Simulated $\mathrm{O}_{3}$ mixing ratios range from $60-100 \mathrm{nmol} \mathrm{mol}^{-1}$ within the anvil, similar to observations. Only the C. Wang and RAMS models show some downward intrusion of $\mathrm{O}_{3}$ on the SSW upper edge of the anvil (note the change in vertical gradient of $\mathrm{O}_{3}$ at $\mathrm{z}=13.5 \mathrm{~km}$, m.s.l. on the left side of the anvil). Because of the lack of additional observations (particularly above the anvil), it is difficult to conclude what processes contribute to the observed high levels of $\mathrm{O}_{3}$ at the top of the SSW edge of the anvil.

The analyzed gas-phase NO mixing ratios from observations have peaks of $\mathrm{NO}$ of over $500 \mathrm{pmol} \mathrm{mol}^{-1}$ (Fig. 10) within a broad region of $\mathrm{NO}>200 \mathrm{pmol} \mathrm{mol}^{-1}$. Note that the observations are of NO while the model results are of 

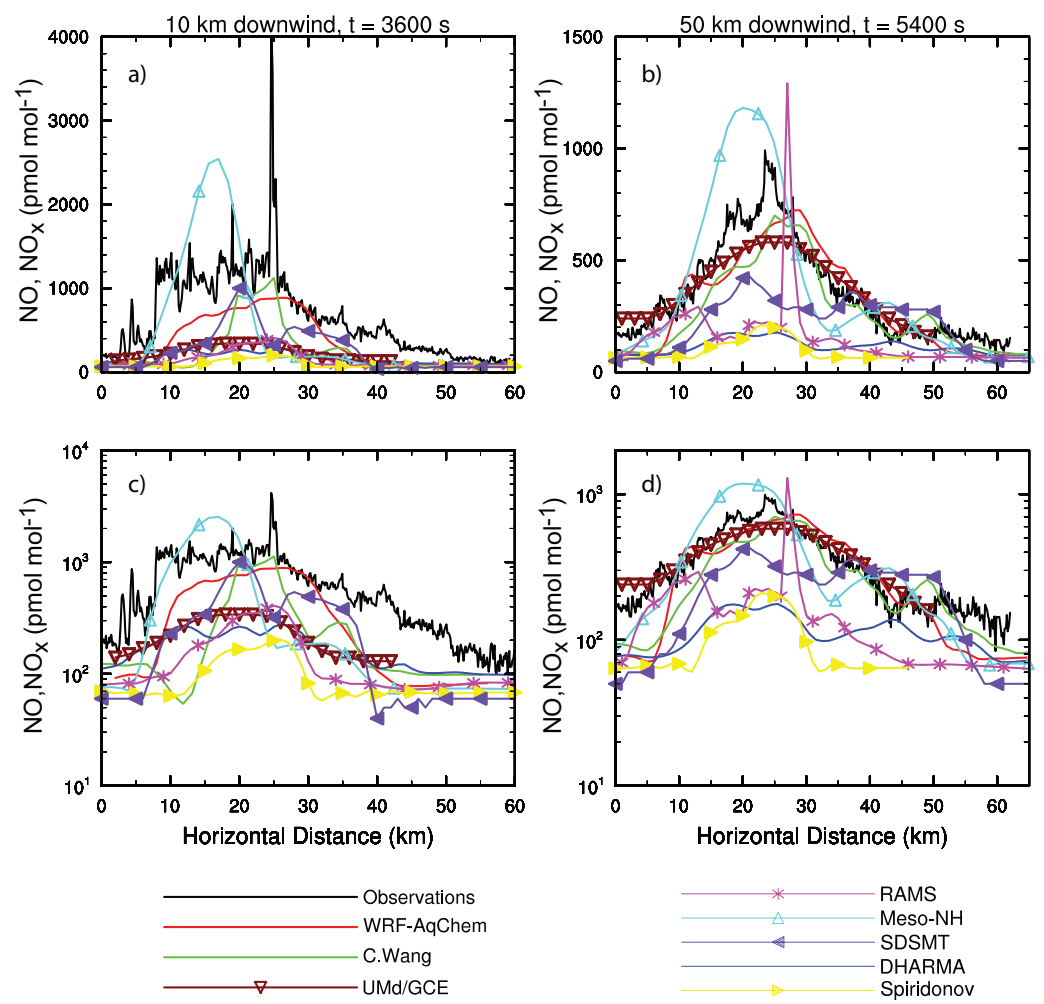

Fig. 6. NO measurements (black lines) from the UND-Citation aircraft for across-anvil transects at $10 \mathrm{~km}$ downwind of the south-easternmost convective cell and $11.6 \mathrm{~km}$ m.s.l. (left panels) and at $50 \mathrm{~km}$ downwind of the south-easternmost convective cell and $11.2 \mathrm{~km} \mathrm{m.s.l}$. (right panels). Results from model calculations of $\mathrm{NO}_{\mathrm{x}}$ are plotted along these transects. $\mathrm{NO}_{\mathrm{x}}$ is plotted on a linear scale in the upper panels, and on a logarithmic scale in the lower panels.
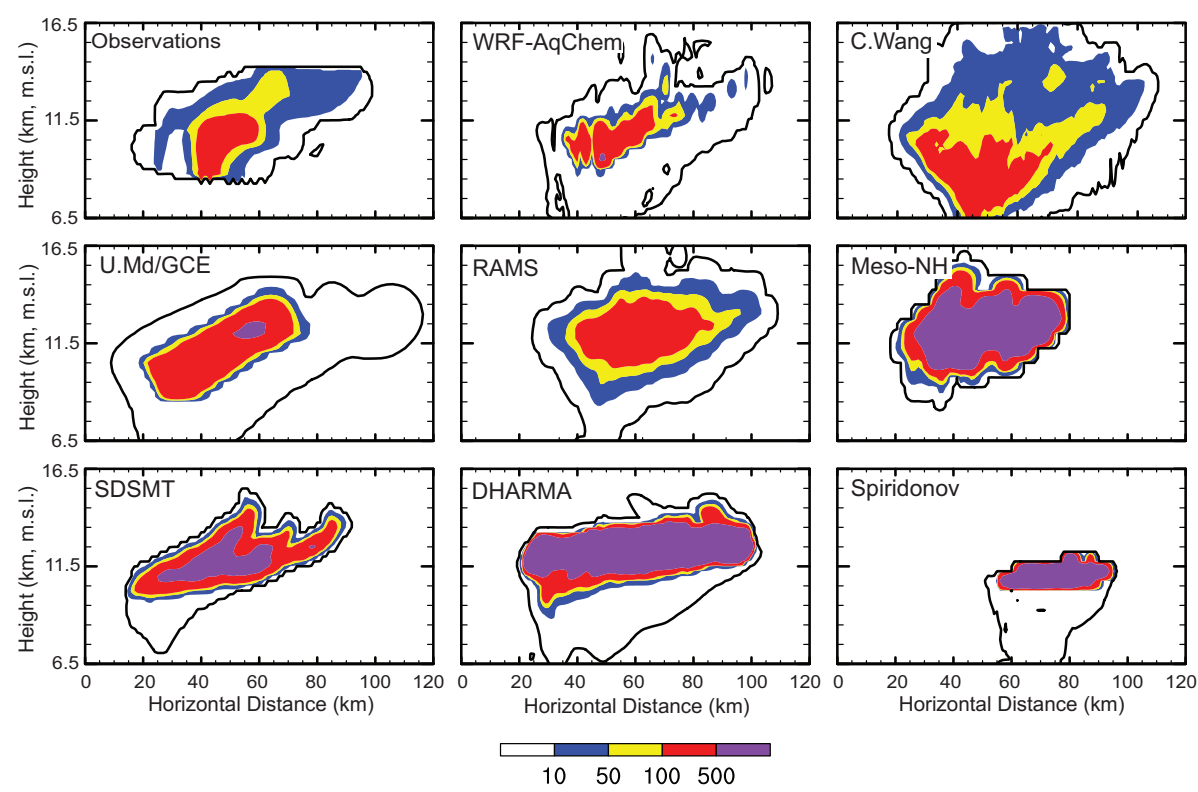

Fig. 7. Cloud particle concentration (per liter) across the anvil at $t=23: 16$ to $t=00: 36$ UTC for the observations and $t=6000 \mathrm{~s}$ for the model results. The location of the cross-section is similar to transect 2 (T2) shown in Fig. 3. The solid black line is cloud particle concentration equal to 0.1 per liter. Objective analysis of the aircraft measurements (upper left panel) are from Skamarock et al. (2003). Model results are for the WRF-AqChem, C. Wang, UMd/GCE, RAMS, Meso-NH, SDSMT, DHARMA, and Spiridonov models. 

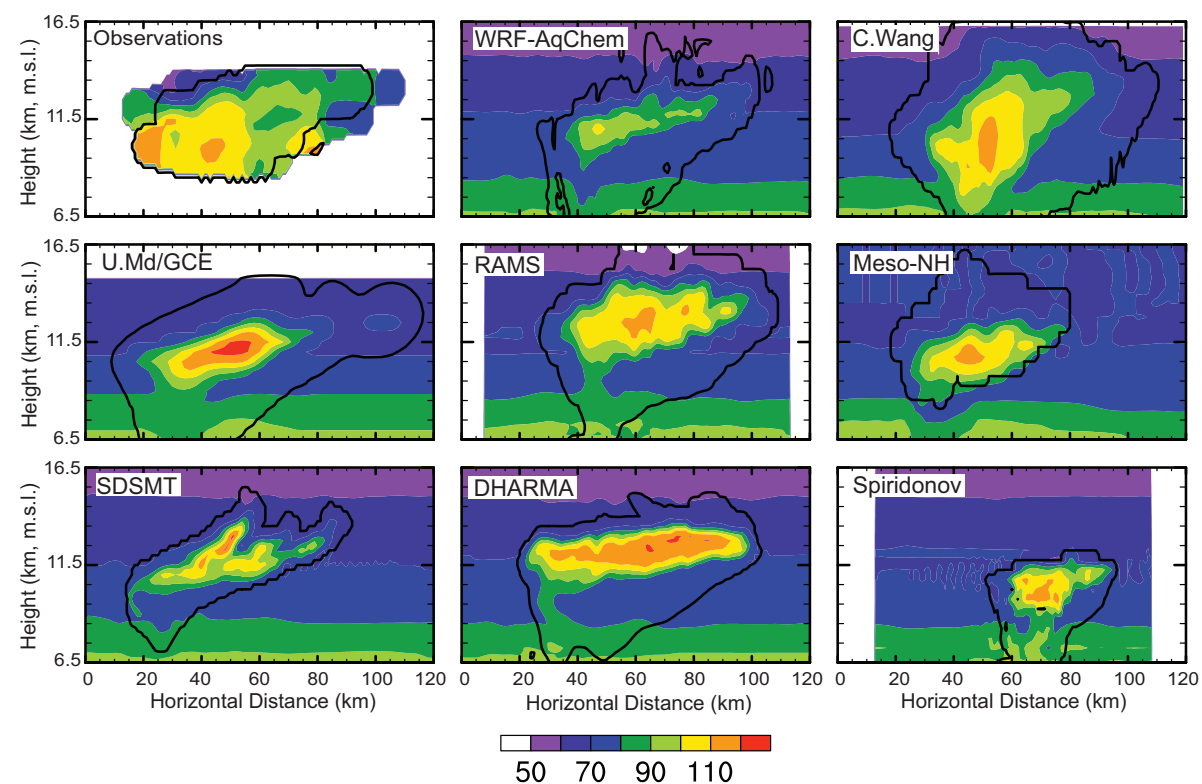

$\begin{array}{llll}50 & 70 & 90 & 110\end{array}$

Fig. 8. Same as Fig. 7 except for $\mathrm{CO}\left(\mathrm{nmol} \mathrm{mol}^{-1}\right)$. The solid black line is cloud particle concentration equal to 0.1 per liter.
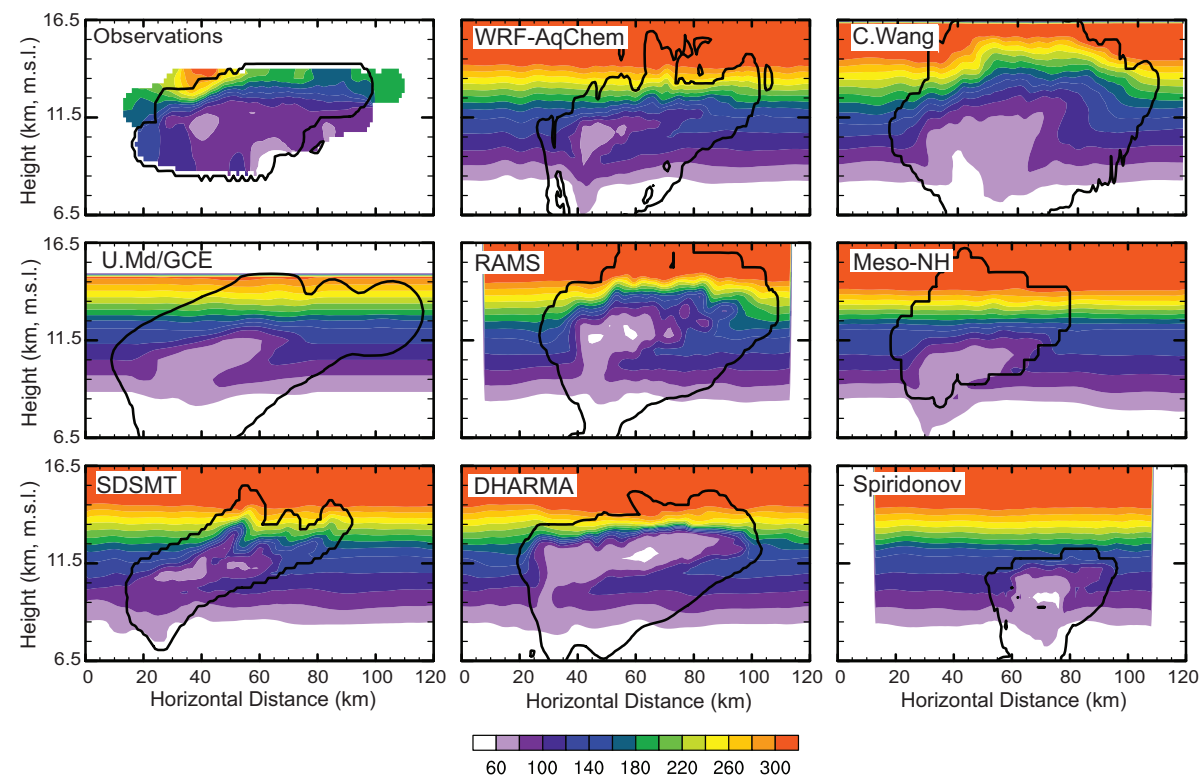

$\begin{array}{lllllll}60 & 100 & 140 & 180 & 220 & 260 & 300\end{array}$

Fig. 9. Same as Fig. 7 except for $\mathrm{O}_{3}\left(\mathrm{nmol} \mathrm{mol}^{-1}\right)$. The solid black line is cloud particle concentration equal to 0.1 per liter.

$\mathrm{NO}_{\mathrm{x}}$. By assuming photochemical equilibrium between $\mathrm{NO}$ and $\mathrm{NO}_{2}, \mathrm{NO}_{\mathrm{x}}$ mixing ratios are 1.1 to 1.6 times greater than NO mixing ratios (Skamarock et al., 2003). Thus, modeled gas-phase $\mathrm{NO}_{\mathrm{x}}$ should be $\sim 30 \%$ greater than the observed NO in the middle of the anvil. Results from models that did not include production of $\mathrm{NO}_{\mathrm{x}}$ from lightning (DHARMA, Spiridonov) do not predict the $\mathrm{NO}_{\mathrm{x}}>500 \mathrm{pmol} \mathrm{mol}^{-1}$ peaks, but instead show $\mathrm{NO}_{\mathrm{x}} \sim 200 \mathrm{pmol} \mathrm{mol}^{-1}$ in the anvil; much less than that observed. The models with production of $\mathrm{NO}_{\mathrm{x}}$ from lightning (WRF-AqChem, C. Wang, UMd/GCE, RAMS, Meso-NH and SDSMT) do predict peaks of $\mathrm{NO}_{\mathrm{x}}$ on the same order of magnitude as the observations. These models also have a broad region of $\mathrm{NO}_{\mathrm{x}}$ mixing ratios between 150 and $250 \mathrm{pmol} \mathrm{mol}^{-1}$, similar to those seen in the observations. To obtain the observed peak values of the $\mathrm{NO}_{\mathrm{x}}$, production from lightning must be modeled.

\subsection{Mass fluxes in the anvil outflow}

Utilizing the modeled mixing ratio $(C)$ in the anvil crosssections (shown in Figs. 8-10) and the horizontal velocity $\left(U_{\perp}\right)$ perpendicular to the cross-section plane, estimates of 



$60 \quad 140 \quad 220300 \quad 380 \quad 460 \quad 540$

Fig. 10. Same as Fig. 7 except for $\mathrm{NO}, \mathrm{NO}_{\mathrm{x}}$. Observations show $\mathrm{NO}$ mixing ratios $\left(\mathrm{pmol} \mathrm{mol}^{-1}\right)$ and models show $\mathrm{NO}_{\mathrm{x}}$. The solid black line is cloud particle concentration equal to 0.1 per liter.

mass fluxes can be made. Corresponding mass fluxes of air, $\mathrm{CO}$, and $\mathrm{NO}_{\mathrm{x}}$ are derived from the aircraft measurements (Skamarock et al., 2003) for comparison to the model results. The calculation of the modeled mass flux density is

flux $=\frac{\sum_{\text {anvil cells }} \rho U_{\perp} C \Delta \ell \Delta z}{\sum_{\text {anvil cells }} \Delta \ell \Delta z}$

where $\Delta \ell$ and $\Delta z$ are the horizontal and vertical grid cell spacing within the anvil. The flux density is determined only in the region where cloud particles exist in the anvil.

Table 4 lists the anvil area as well as the fluxes of air mass, $\mathrm{CO}$, and $\mathrm{NO}_{\mathrm{x}}$ averaged over a $1 \mathrm{~h}$ time period, which is comparable to the time period of the aircraft measurements. Each model's average mass flux can be compared to the mass flux derived from observations, which was determined by Skamarock et al. (2003) from the analyzed cross section.

While the analyzed anvil area taken from the observations is $315 \mathrm{~km}^{2}$, the modeled anvil area ranges from $109 \mathrm{~km}^{2}$ to $590 \mathrm{~km}^{2}$, which are within -65 and $90 \%$ of the analyzed observed area. The air mass flux determined from the observations is $5.9 \mathrm{~kg} \mathrm{~m}^{-2} \mathrm{~s}^{-1}$, while those predicted by the models range from 6.6 to $9.1 \mathrm{~kg} \mathrm{~m}^{-2} \mathrm{~s}^{-1}$. Note that there is also some uncertainty in the observed anvil area and flux densities (Skamarock et al., 2003) associated with uncertainties in the in situ measurements and in temporal changes in these measured species and in the anvil crosssection area as the measurements were taken. All of the models overpredict the air mass flux, suggesting that the modeled wind speeds in the anvil are too strong. The CO flux density calculation from the observational analysis is
$1.9 \times 10^{-5}$ moles $\mathrm{m}^{-2} \mathrm{~s}^{-1}$, while the modeled CO flux densities range from 1.93 to $2.8 \times 10^{-5}$ moles $\mathrm{m}^{-2} \mathrm{~s}^{-1}$. We find that 4 models are within $5 \%$ of the analyzed CO flux density and a total of 7 models are within 33\%. However, because the air mass flux is over-predicted by all models, a correction to the air mass flux density would result in CO flux densities for all models being smaller than the analysis of the measurements. The $\mathrm{NO}_{\mathrm{x}}$ flux density derived from the observations includes $\mathrm{NO}_{\mathrm{x}}$ produced from lightning and has a value of $5.8 \times 10^{-8}$ moles m$^{-2} \mathrm{~s}^{-1}$. The $\mathrm{NO}_{\mathrm{x}}$ flux densities determined from models without lightning- $\mathrm{NO}_{\mathrm{x}}$ production (DHARMA, Spiridonov) are $4.3 \times 10^{-8}$ and $2.7 \times 10^{-8}$ moles $\mathrm{m}^{-2} \mathrm{~s}^{-1}$, while the models that do include lightning- $\mathrm{NO}_{x}$ production are between 3.9 and $13.0 \times 10^{-8}$ moles $\mathrm{m}^{-2} \mathrm{~s}^{-1}$. We find that the variability among the modeled $\mathrm{NO}_{\mathrm{x}}$ flux densities is clearly higher than that for the air mass or $\mathrm{CO}$ flux densities.

One of the unique features of this intercomparison exercise is that of the 6 models that simulated lightning production of $\mathrm{NO}_{\mathrm{x}}$ there are 5 different schemes used. Two schemes (Meso-NH and SDSMT) explicitly predict the charge coincident with the hydrometeors, locate the NO source along the lightning channel using a fairly small NO production value (36 and 97 moles NO/flash for Meso-NH and SDSMT, respectively). The WRF-AqChem and UMd/GCE models use the same lightning- $\mathrm{NO}_{\mathrm{x}}$ parameterization in which observed lightning flash rates are used as input and categorized as CG or IC flashes. The NO produced from lightning is uniformly placed in the $>20 \mathrm{dBZ}$ region with Gaussian (CG) or bimodal (IC) vertical distributions. Fairly high production of NO (395 moles NO/CG flash; 195 moles NO/IC 
Table 4. Anvil cross-sectional area, dry air mass flux density, and species flux density from each model simulation averaged over a $1 \mathrm{~h}$ time period.

\begin{tabular}{lllll}
\hline Model & $\begin{array}{l}\text { Anvil Area } \\
\left(10^{6} \mathrm{~m}^{2}\right)\end{array}$ & $\begin{array}{l}\text { Mass Flux } \\
\left(\mathrm{kg} \mathrm{m}^{-2} \mathrm{~s}^{-1}\right)\end{array}$ & $\begin{array}{l}\text { CO Flux } \\
\left(10^{-5} \mathrm{~mol} \mathrm{~m}^{-2} \mathrm{~s}^{-1}\right)\end{array}$ & $\begin{array}{l}\mathrm{NO}_{\mathrm{x}} \text { Flux } \\
\left(10^{-8} \mathrm{~mol} \mathrm{~m}^{-2} \mathrm{~s}^{-1}\right)\end{array}$ \\
\hline Observations & 315 & 5.9 & 1.90 & $5.8^{*}$ \\
WRF-AqChem & $187.7 \pm 55.8$ & $6.75 \pm 0.23$ & $1.94 \pm 0.05$ & $7.23 \pm 2.31$ \\
C. Wang & $442.7 \pm 170.4$ & $6.72 \pm 0.26$ & $1.94 \pm 0.07$ & $5.97 \pm 0.31$ \\
U. Md/GCE & $274.0 \pm 150$ & $9.02 \pm 0.12$ & $2.54 \pm 0.17$ & $8.41 \pm 1.71$ \\
RAMS & $332.7 \pm 195.5$ & $7.68 \pm 0.57$ & $2.29 \pm 0.08$ & $5.30 \pm 0.89$ \\
Meso-NH & $590.0 \pm$ n.a. & $6.73 \pm 0.05$ & $1.93 \pm 0.02$ & $3.93 \pm 0.14$ \\
SDSMT & $196.9 \pm 27.6$ & $6.59 \pm 0.22$ & $1.93 \pm 0.08$ & $13.04 \pm 2.74$ \\
DHARMA & $382.2 \pm 119.5$ & $8.13 \pm 0.13$ & $2.35 \pm 0.09$ & $4.28 \pm 0.17$ \\
V. Spiridonov & $109.0 \pm 61.6$ & $9.13 \pm 0.28$ & $2.79 \pm 0.18$ & $2.66 \pm 0.44$ \\
avg +/- std dev & $314.4 \pm 156.3$ & $7.60 \pm 1.07$ & $2.21 \pm 0.33$ & $6.36 \pm 3.27$ \\
\hline
\end{tabular}

Individual model averages and standard deviations are for $t=3600$ to $t=7200 \mathrm{~s}$ of the integration, sampled at 10 min intervals. The bottom line shows average and standard deviations for all models. DHARMA and Spiridonov models do not include lightning production of NO.

* The $\mathrm{NO}_{\mathrm{X}}$ flux from the observations assumes $\mathrm{NO}_{\mathrm{x}}=1.3 \mathrm{NO}$.

flash) is prescribed. The RAMS model uses the Pickering et al. (1998) lightning parameterization that calculates the lightning flash rate based on the maximum updraft speed (which is based on Price and Rind, 1992). NO is placed in the $>20 \mathrm{dBZ}$ region either below the $-15^{\circ} \mathrm{C}$ isotherm (CG flashes) or above the $-15^{\circ} \mathrm{C}$ isotherm (IC flashes). The type of flash depends on the depth of the storm above the freezing level (in this case $4 \%$ of the flashes are CG), and the amount of NO produced is 1113 moles NO/CG flash and 111 moles NO/IC flash based on Price et al. (1997). The C. Wang model calculates the lightning flash rate based on the graupel-ice collision rates. The NO is placed in regions $>20 \mathrm{dBZ}$ similarly to the UMd/GCE formulation. The amount of NO produced per flash is 465 moles.

By comparing Figs. 6 and 10 with Table 4, a few interesting features are noted. While both explicit models (MesoNH and SDSMT) show very good agreement with NO observations in the $50 \mathrm{~km}$ downwind transect and cross-section (which give a snapshot of results), the Meso-NH model underpredicts the $\mathrm{NO}_{\mathrm{x}}$ flux and the SDSMT model overpredicts the $\mathrm{NO}_{\mathrm{x}}$ flux (which gives a time-integrated result). Several reasons could explain these discrepancies including the normalization by the anvil area (the Meso-NH anvil area $>$ observations, while the SDSMT anvil area $<$ observations), or the lack of lightning activity in the Meso-NH model for $2 / 3$ of the flux sampling time (Barthe et al., 2007). The lightning flash rates predicted by the C. Wang (5-15 flashes/min), RAMS (20-25 flashes/min), Meso-NH (18-30 flashes/min), and SDSMT (8-16 flashes/min) models are all less than to about the same as that observed (20-35 flashes/min) indicating that the flash rate does not significantly contribute to uncertainties in the $\mathrm{NO}_{\mathrm{x}}$ mixing ratios in the anvil region. Both the explicit models use low NO production per flash but place the NO in a small volume (along the lightning channel). In comparison, the other 4 parameterizations use higher $\mathrm{NO}$ production per flash placed in a larger region to get a similar result to the explicit simulations and to the observations. This implies that the more simple parameterizations compensate the large volume of NO placement with higher NO production per flash. Thus, getting more exact locations of the NO production region with respect to the lightning channel, the updrafts and downdrafts is very much needed. Lastly, the variability seen within models and among models indicates the need for further refinement of current lightning- $\mathrm{NO}_{\mathrm{x}} \mathrm{pa}-$ rameterizations.

\subsection{Distributions of $\mathrm{CH}_{2} \mathrm{O}, \mathrm{H}_{2} \mathrm{O}_{2}$, and $\mathrm{HNO}_{3}$}

Soluble and reactive chemical species, such as formaldehyde, hydrogen peroxide and nitric acid, are important to tropospheric ozone chemistry. In simulating $\mathrm{CH}_{2} \mathrm{O}, \mathrm{H}_{2} \mathrm{O}_{2}$, and $\mathrm{HNO}_{3}$, species with different solubility coefficients and different chemical reactivity are represented. Because there were no observations of $\mathrm{CH}_{2} \mathrm{O}, \mathrm{H}_{2} \mathrm{O}_{2}$, and $\mathrm{HNO}_{3}$ in the outflow region of the 10 July 1996 STERAO storm, comparisons to measurements are not possible. While other field campaigns (further details are discussed below) have measured one or more of these species near convection, none of the campaigns have done a budget (detrained species in the anvil minus entrained species into the convective core) nor have the measurements been near the storm core as these model results are. These previous field campaigns have shown some enhancement of $\mathrm{CH}_{2} \mathrm{O}$ and $\mathrm{H}_{2} \mathrm{O}_{2}$ and strong depletion of gas-phase $\mathrm{HNO}_{3}$ in convective outflow regions compared to their background upper troposphere mixing ratios. Here, we compare gas-phase mixing ratios for these 3 species to find similarities and differences among model approaches. How the simulated results compare to past field campaigns is discussed at the end of the section. 

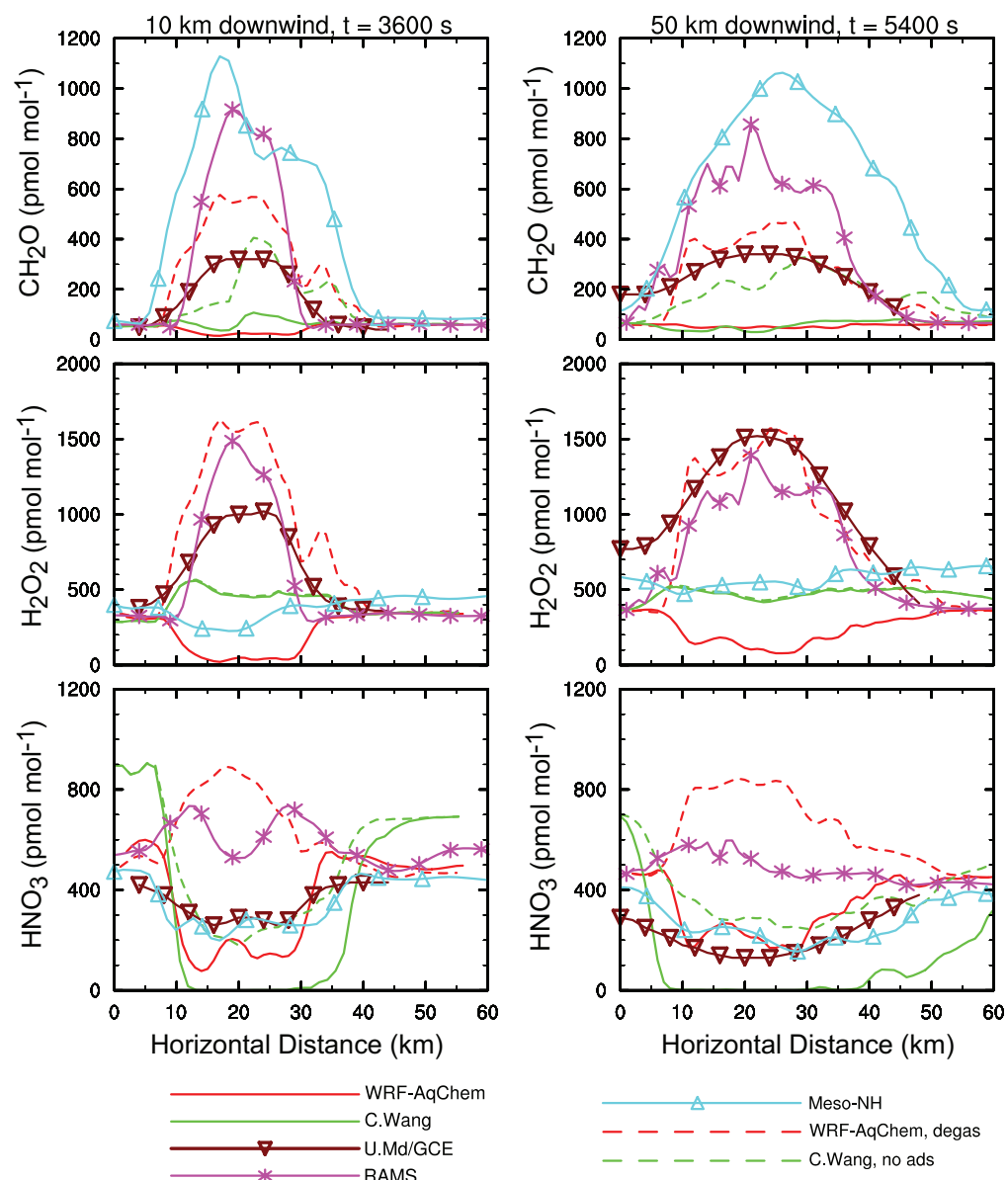

Fig. 11. $\mathrm{CH}_{2} \mathrm{O}, \mathrm{H}_{2} \mathrm{O}_{2}$, and $\mathrm{HNO}_{3}$ mixing ratios from different models for across-anvil transects at $10 \mathrm{~km}$ downwind of the south-easternmost convective cell and $11.6 \mathrm{~km} \mathrm{~m} . \mathrm{s} .1$. (left panels) and at $50 \mathrm{~km}$ downwind of the south-easternmost convective cell and $11.2 \mathrm{~km}$ m.s.l. (right panels).

The soluble, reactive species are simulated by 5 models: WRF-AqChem, C. Wang, UMd/GCE, RAMS, and Meso-NH. Model results along the same two aircraft transects are used for the comparison (Fig. 11). In contrast to the $\mathrm{CO}$ and $\mathrm{O}_{3}$ results, the modeled $\mathrm{CH}_{2} \mathrm{O}, \mathrm{H}_{2} \mathrm{O}_{2}$, and $\mathrm{HNO}_{3}$ gas-phase mixing ratios vary significantly among models. For $\mathrm{CH}_{2} \mathrm{O}$, the Meso-NH, RAMS, and UMd/GCE simulations have enhanced $\mathrm{CH}_{2} \mathrm{O}$ mixing ratios compared to their values in the background upper troposphere. The WRFAqChem and C. Wang simulations have anvil mixing ratios that are depleted or similar to the background upper troposphere mixing ratios. One explanation for the disagreement among model results is the manner in which soluble species are treated with the ice phase. The Meso-NH, RAMS, and UMd/GCE models do not include soluble species in the ice phase while WRF-AqChem and C. Wang models do. Both the WRF-AqChem and C. Wang models use a retention efficiency of $100 \%$ when cloud and rain drops freeze. Thus, in these two models the $\mathrm{CH}_{2} \mathrm{O}$ in the snow and hail is precipitated with their parent hydrometeor, transferred to the rain via melting, and rained onto the ground (Barth et al., 2001, 2007). The WRF-AqChem, degas curves in Fig. 11 illustrate the effect of not including soluble species in the ice phase. A second explanation for differences in $\mathrm{CH}_{2} \mathrm{O}$ mixing ratios is the effect of chemistry. The WRF-AqChem, C. Wang and RAMS models include gas-phase and aqueous chemistry, while the UMd/GCE model includes only gaseous chemistry, and the Meso-NH model does not include either gas or aqueous chemistry. Previous studies (Leriche et al., 2007; Barth et al., 2007) showed that both gas-phase and aqueous chemistry (using a chemistry mechanism without non-methane hydrocarbons) reduce $\mathrm{CH}_{2} \mathrm{O}$ mixing ratios in the anvil. Similarly the assumption of Henry's law equilibrium for gas-aqueous species transfer (UMd/GCE) could reduce gas-phase concentrations. Simulations (not shown) without the production of NO from lightning performed by both the WRF-AqChem and C. Wang models are essentially the same as those shown in Fig. 11 for anvil $\mathrm{CH}_{2} \mathrm{O}$ mixing ratios within $50 \mathrm{~km}$ of the storm core. 
For $\mathrm{H}_{2} \mathrm{O}_{2}$, the UMd/GCE and RAMS model results have enhanced gas-phase mixing ratios in the anvil compared to the background upper troposphere. The C. Wang and Meso-NH model results have similar mixing ratios between the anvil and background upper troposphere, while the WRFAqChem model results have depleted $\mathrm{H}_{2} \mathrm{O}_{2}$ mixing ratios compared to the background upper troposphere. The effect of the ice phase (WRF-AqChem, degas curve) would enhance $\mathrm{H}_{2} \mathrm{O}_{2}$ mixing ratios in the anvil substantially. Lightning production of $\mathrm{NO}$ does not affect the results shown by the WRF-AqChem and C. Wang models. The inclusion of aqueous chemistry does reduce anvil mixing ratios of $\mathrm{H}_{2} \mathrm{O}_{2}$ somewhat (Leriche et al., 2007; Barth et al., 2007). Furthermore, the treatment of the gas-aqueous species transfer could affect results, with the assumption of Henry's law likely reducing gas-phase mixing ratios. Modified photolysis rates may increase $\mathrm{H}_{2} \mathrm{O}_{2}$ mixing ratios. The $\mathrm{C}$. Wang and $\mathrm{UMd} / \mathrm{GCE}$ models include cloud-modified photolysis reaction rates, while the other models do not. However, Barth et al. (2002) showed a very small effect of cloud-modified photolysis rates on $\mathrm{H}_{2} \mathrm{O}_{2}$ mixing ratios in marine boundary layer clouds.

For $\mathrm{HNO}_{3}$, all the models except the RAMS model have anvil gas-phase mixing ratios that are depleted compared to the background upper troposphere. In the RAMS model, the combination of scavenging primarily by small droplets via the diffusion-limited, mass transfer and the degassing of $\mathrm{HNO}_{3}$ during cloud drop freezing contributes to the high anvil mixing ratios, similar to what is shown by the WRFAqChem, degas curves in Fig. 11. The C. Wang $\mathrm{HNO}_{3}$ gas-phase mixing ratios go to zero in the anvil, while other models show values between 200 and $300 \mathrm{pmol} \mathrm{mol}^{-1}$. The discrepancy is explained by adsorption of gas-phase $\mathrm{HNO}_{3}$ onto ice and snow crystals which is included in the $\mathrm{C}$. Wang model. When this process is not included (C. Wang, no ads curve), the $\mathrm{HNO}_{3}$ mixing ratios in the anvil are similar to those predicted by the other models.

For soluble species, such as $\mathrm{CH}_{2} \mathrm{O}, \mathrm{H}_{2} \mathrm{O}_{2}$, and $\mathrm{HNO}_{3}$, many processes affect their fate. Scavenging of these gases by the drops and ice tends to reduce their gas-phase mixing ratios in the anvil. Aqueous chemistry also tends to reduce mixing ratios of $\mathrm{CH}_{2} \mathrm{O}$ and $\mathrm{H}_{2} \mathrm{O}_{2}$. Inclusion of dissolved species in the ice phase substantially reduces the gas-phase mixing ratios of $\mathrm{CH}_{2} \mathrm{O}, \mathrm{H}_{2} \mathrm{O}_{2}$, and $\mathrm{HNO}_{3}$, but this is an uncertain result because of the uncertainties and lack of knowledge concerning the physical and chemical processes occurring when cloud and rain drops freeze. Production of NO by lightning does not affect the gas-phase mixing ratios of these species within $50 \mathrm{~km}$ of the storm core. Their mixing ratios may be affected further downwind as chemical aging occurs.

While measurements of formaldehyde, hydrogen peroxide, and nitric acid were not taken in the convective outflow of the 10 July 1996 STERAO storm, some of these species have been measured during other field campaigns near convection. Stickler et al. (2006) found enhanced upper troposphere $\mathrm{CH}_{2} \mathrm{O}$ mixing ratios over Europe on a day influenced by convection compared to a day representative of background conditions. These measurements were taken well downwind of the convection therefore allowing chemical aging (i.e. production of $\mathrm{CH}_{2} \mathrm{O}$ ) to occur in the convective outflow plume. $\mathrm{H}_{2} \mathrm{O}_{2}$ measurements reported for tropical oceanic convection sampled in PEM Tropics A (Cohan et al., 1999) showed that $\mathrm{H}_{2} \mathrm{O}_{2}$ convective outflow mixing ratios were moderately enhanced $\left(330 \pm 140 \mathrm{pmol} \mathrm{mol}^{-1}\right)$ compared to the unperturbed upper troposphere $\left(200 \pm 110 \mathrm{pmol} \mathrm{mol}^{-1}\right)$. These results support the C. Wang results (Fig. 11), but it must be recognized that the Cohan et al. (1999) measurements sampled tropical, oceanic convection (characterized by more liquid water and less ice) compared to the midlatitude, continental convection simulated in this study. Measurements of $\mathrm{HNO}_{3}$ (Popp et al., 2004) revealed large depletions of gaseous $\mathrm{HNO}_{3}$ in cirrus sampled during the CRYSTAL-FACE experiment in Florida. Their measurements are in agreement with the models showing gas-phase $\mathrm{HNO}_{3}$ depleted mixing ratios (Fig. 11).

\section{Conclusions}

The intercomparison of convective scale cloud chemistry models simulating constituent transport in deep convection is the first of its kind. Simulations were performed based on the same initial conditions and similar model domain configurations. All eight models that participated in the intercomparison have reproduced the observed multicellular convection with radar reflectivity reaching $>50 \mathrm{dBZ}$. Comparisons of carbon monoxide and ozone, which are primarily transported in convection, showed good agreement among models and with observations especially within the anvil. The models that included lightning production of nitric oxide predicted $\mathrm{NO}_{\mathrm{x}}$ mixing ratios of similar magnitude to observed NO mixing ratios indicating that $\mathrm{NO}$ production from lightning is a key process to include for understanding the composition of convective outflow regions. Furthermore, the relatively good agreement with observations show that current cloud-scale parameterizations of lightning production of $\mathrm{NO}$ seem to be capturing the key parameters (lightning flash rate which depends on the storm kinematic and microphysical characteristics, lightning type, NO source location, NO production per lightning flash) of this process. However, these same parameters play an important role in contributing to uncertainties in $\mathrm{NO}_{\mathrm{x}}$ mixing ratios in convective outflow. Placement of the NO source and its volume within the storm is a critical uncertainty for which additional observations are needed.

Calculations of the anvil fluxes of air, $\mathrm{CO}$ and $\mathrm{NO}_{\mathrm{x}}$ are compared between models and analyzed observations. The models consistently overestimate the flux density of air compared to the observed value, but flux densities of $\mathrm{CO}$ agree quite well with the observed value. The deviation among the models is $20 \%$ and less for the air and CO flux densities. 
Predicted $\mathrm{NO}_{\mathrm{x}}$ flux densities are significantly more variable and tend to be greater than that estimated from observations.

Formaldehyde, hydrogen peroxide, and nitric acid, species that are soluble and chemically reactive, are compared just among the different models because observations of these species were not made in the anvil region of the observed storm. For all 3 species, the models produced very different results indicating the need for measurements of these species in the anvil region concurrently with measurements in the inflow region to better understand their convective processing. Potential reasons for the discrepancies among the models include the role of the ice phase, the impact of cloud-modified photolysis rates on these species mixing ratios, and representation of their chemical reactivity.

To improve parameterizations of convective transport of constituents in large-scale models, we can use these models to obtain general characteristics (e.g. vertical mass fluxes, wet deposition rates, and production rates of NO from lightning) of chemical constituent transport in a variety of convection types. Simulations of the same convection cases at both the cloud resolving scale (as discussed in this paper) and at larger scales (in which the convection is parameterized) either using a single column version of the model (e.g. Ovtchinnikov and Ghan, 2005) or the 3-D version would provide a valuable means to assess the merit of convective transport and lightning- $\mathrm{NO}_{\mathrm{x}}$ parameterizations in large-scale models. In addition, further testing of cloud resolving models and large scale models needs to be pursued with new field experiment datasets that are focused on collecting data for budget analysis of a variety of chemical species.

Acknowledgements. The discussions and contributions of initial conditions and analyzed observations from B. Skamarock are greatly appreciated. More information on the intercomparison can be found at http://box.mmm.ucar.edu/people/barth/files/ Chem_Convec_Intercomparison/tracertransportdeepconvection.

html. W. Deierling is thanked for providing the radar-derived maximum updraft speeds and heights. The University of Maryland/Rutgers investigators thank W.-K. Tao for use of the Goddard Cumulus Ensemble Model to drive the cloud chemistry calculations. J. Helsdon and R. Farley acknowledge the NSF Atmospheric Chemistry Program under Grant ATM-0321985 for support of the SDSMT part of the research. The National Center for Atmospheric Research is operated by the University Corporation for Atmospheric Research under the sponsorship of the National Science Foundation.

\section{Edited by: U. Lohmann}

\section{References}

Ackerman, A. S., Toon, O. B., and Hobbs, P. V.: A model for particle microphysics, turbulent mixing, and radiative-transfer in the stratocumulus-topped marine boundary-layer and comparisons with measurements, J. Atmos. Sci., 52, 1204-1236, 1995.

Allen, D. J., Douglass, A. R., and Rood, R. B.: Applications of a monotonic upstream transport scheme to three-dimensional con- stituent transport calculations, Mon. Weather Rev., 119, 24562464, 1991.

Arakawa, A.: Computational design for long term integration of the equations of motion: Two-dimensional incompressible flow, J. Comput. Phys., 1, 119-143, 1966.

Arteta, J., Cautenet, S., Taghavi, M., and Audiffren, N.: Impact of two chemistry mechanisms fully coupled with mesoscale model on the atmospheric pollutants distribution, Atmos. Environ., 40, 7983-8001, 2006.

Audiffren, N., Renard, M., Buisson, E., and Chaumerliac, N.: Deviations from the Henry's law equilibrium during cloud events: A numerical approach of the mass transfer between phases and its specific numerical effects, Atmos. Res., 49, 139-161, 1998.

Barth, M. C., Stuart, A. L., and Skamarock, W. C.: Numerical simulations of the July 10 STERAO/Deep Convection storm: Redistribution of soluble tracers, J. Geophys. Res., 106, $12381-$ 12 400, 2001.

Barth, M. C., Hess, P. G., and Madronich, S.: Effect of marine boundary layer clouds on tropospheric chemistry as analyzed in a regional chemistry transport model, J. Geophys. Res., 107, 4126, doi:10.1029/2001JD000468, 2002.

Barth, M. C., Kim, S.-W., Skamarock, W. C., Stuart, A. L., Pickering, K. E., and Ott, L. E.: Simulations of the redistribution of formaldehyde, formic acid, and peroxides in the July 10, 1996 STERAO deep convection storm, J. Geophys. Res., 112, D13310, doi:10.1029/2006JD008046, 2007.

Barthe, C., Molinie, G., and Pinty, J.-P.: Description and first results of an explicit electrical scheme in a 3D cloud resolving model, Atmos. Res., 76, 95-113, 2005.

Barthe, C., Pinty, J.-P., and Mari, C.: Lightning-produced $\mathrm{NO}_{\mathrm{x}}$ in an explicit electrical scheme tested in a Stratosphere-Troposphere Experiment: Radiation, Aerosols, and Ozone case study, J. Geophys. Res., 112, D04302, doi:10.1029/2006JD007402, 2007.

Bott, A.: A positive definite advection scheme obtained by nonlinear renormalization of the advective fluxes, Mon. Weather Rev., 117, 1006-1015, 1989.

Bott, A.: The monotone area-preserving flux-form advection algorithm: Reducing the time-splitting error in two-dimensional flow fields, Mon. Weather Rev., 121, 2637-2641, 1993.

Clark, T. L.: A small-scale dynamic model using a terrain-following coordinate transformation, J. Comput. Phys., 24, 186-215, 1977.

Clark, T. L.: Numerical simulations with a three-dimensional cloud model: Lateral boundary condition experiments and multicellular severe storm simulations, J. Atmos. Sci., 36, 2191-2215, 1979.

Clark, T. L. and Farley, R. D.: Severe downslope windstorm calculations in two and three spatial dimensions using anelastic interactive grid nesting: A possible mechanism for gustiness, J. Atmos. Sci., 41, 329-350, 1984.

Clark, T. L. and Hall, W. D.: Multi-domain simulations of the time dependent Navier Stokes equation: Benchmark error analyses of nesting procedures, J. Comp Phys., 92, 456-481, 1991.

Cohan, D. S., Schultz, M. G., Jacob, D. J., Heikes, B. G., Blake, D. R.: Convective injection and photochemical decay of peroxides in the tropical upper troposphere: Methyl iodide as a tracer of marine convection, J. Geophys. Res., 104, 5717-5724, 1999.

Cotton, W. R., Pielke Sr., R. A., Walko, R. L, Liston, G. E., Tremback, C. J., Jiang, H., McAnelly, R. L., Harrington, J. Y., Nicholls, M. E., Carrio, G. G., and McFadden, J. P.: RAMS 
2001: Current status and future directions, Meteorol. Atmos. Phys., 82, 5-29, 2003.

Deardorff, J. W.: The development of boundary layer turbulence models for use in studying the severe storm environment, Proceedings of the SESAME Opening Meeting, Boulder, NOAAERL, p. 251-264, 1975.

DeCaria, A. J., Pickering, K. E., Stenchikov, G. L., Scala, J. R., Stith, J. L., Dye, J. E., Ridley, B. A., and Laroche, P.: A cloud-scale model study of lightning-generated $\mathrm{NO}_{\mathrm{x}}$ in an individual thunderstorm during STERAO-A, J. Geophys. Res., 105, 11 601-11 616, 2000.

DeCaria, A. J., Pickering, K. E., Stenchikov, G. L., and Ott, L. E.: Lightning-generated $\mathrm{NO}_{\mathrm{x}}$ and its impact on tropospheric ozone production: A 3-D modeling study of a STERAO-A thunderstorm, J. Geophys. Res., 110, D14303, doi:10.1029/2004JD005556, 2005.

Dye, J. E., Ridley, B. A., Baumann, K., Skamarock, W. C., Barth, M. C., Venticinque, M., Defer, E., Blanchet, P., Thery, C., Laroche, P., Hubler, G., Parrish, D. D., Ryerson, T., Trainer, M., Frost, G., Holloway, J. S., Fehsenfeld, F. C., Tuck, A., Matejka, T., Bartels, D., Rutledge, S. A., Lang, T., Stith, J., and Zerr, R.: An Overview of the STERAO-Deep Convection Experiment with Results for the 10 July Storm, J. Geophys. Res., 105, 10 023-10 045, 2000.

Ekman, A., Wang, C., Ström, J., and Wilson, J.: Explicit simulation of aerosol physics in a cloud-resolving model: A sensitivity study based on an observed convective cloud, Atmos. Chem. Phys., 4, 773-791, 2004, http://www.atmos-chem-phys.net/4/773/2004/.

Ekman, A., Wang, C., Ström, J., and Krejci, R.: Explicit simulation of aerosol physics in a cloud-resolving model: Aerosol transport and processing in the free troposphere, J. Atmos. Sci., 63, 682696, 2006.

Fridlind, A. M., Ackerman, A. S., Jensen, E. J., Heymsfield, A. J., Poellot, M. R., Stevens, D. E., Wang, D., Miloshevich, L. M., Baumgardner, D., R. Lawson, P., Wilson, J. C., Flagan, R. C., Seinfeld, J. H., Jonsson, H. H., VanReken, T. M., Varutbangkul, V., and Rissman, T. A.: Evidence for the predominance of midtropospheric aerosols as subtropical anvil cloud nuclei, Science, 304, 718-722, doi:10.1126/science.1094947, 2004.

$\mathrm{Fu}, \mathrm{Q}$. and Liou, K. N.: Parameterization of the radiative properties of cirrus clouds, J. Atmos. Sci., 50, 2008-2025, 1993.

Grabowski, W. W.: Sixth WMO International Cloud Modeling Workshop, B. Am. Meteor. Soc., 87, 639-642, 2006.

Helsdon Jr., J. H. and Farley, R. D.: A numerical modeling study of a Montana thunderstorm, 2, Model results vs. observations involving electrical aspects, J. Geophys. Res., 92, 5661-5675, 1987.

Helsdon Jr., J. H., Wu, G., and Farley, R. D.: An intracloud lightning parameterization scheme for a storm electrification model, J. Geophys. Res., 97, 5865-5884, 1992.

Helsdon Jr., J. H., Wojcik, W. A., and Farley, R. D.: An examination of thunderstorm charging mechanisms using a two-dimensional storm electrification model, J. Geophys. Res., 106, 1165-1192, 2001

Helsdon Jr., J. H., Gattaleeradapan, S., Farley, R. D., and Waits, C. C.: An examination of the convective charging hypothesis: charge structure, electric fields, and Maxwell currents, J. Geophys. Res., 107(D22), 4630, doi:10.1029/2001JD001495, 2002.
Hindmarsh, A. C.: ODEPACK, A systematized collection of ODE solvers, in Scientific Computing, edited by: Stepleman, R. S., IMACS/North Holland Publishing Company, New York, 55-64, 1983.

Houze Jr., R. A.: Cloud Dynamics, Academic Press, San Diego, $573 \mathrm{pp}, 1993$.

Jacobson, M. Z.: Computation of global photochemistry with SMVGEAR-II, Atmos. Environ., 29, 2541-2546, 1995.

Jaeglé, L., Jacob, D. J., Wang, Y., Weinheimer, A. J., Ridley, B. A., Campos, T. L., Sachse, G. W., and Hagen, D. E.: Sources and chemistry of $\mathrm{NO}_{\mathrm{x}}$ in the upper troposphere over the United States, Geophys. Res. Lett., 25, 1705-1708, 1998.

Jensen E. J., Ackerman, A. S., Stevens, D. E., Toon, O. B., and Minnis, P.: Spreading and growth of contrails in a sheared environment, J. Geophys. Res., 103, 31 557-31 567, 1998.

Kessler, E.: On the distribution and continuity of water substance in atmospheric circulations, Meteorol. Monogr., 10(32), 84 pp., 1969.

Klemp, J. B. and Wilhelmson, R. B.: Simulation of 3-dimensional convective storm dynamics, J. Atmos. Sci., 35, 1070-1096, 1978a.

Klemp, J. B. and Wilhelmson, R. B.: Simulations of right- and leftmoving storms produced through storm splitting, J. Atmos. Sci., 35, 1097-1110, 1978b.

Lafore, J.-P., Stein, J., Asencio, N., Bougeault, P., Ducrocq, V., Duron, J., Fischer, C., Héreil, P., Mascart, P., Masson, V., Pinty, J.-P., Redelsperger, J.-L., Richard, E., and Vilà-Guerau de Arellano, J.: The Meso-NH Atmospheric Simulation System. Part I: Adiabatic formulation and control simulations, Ann. Geophys., 16, 90-109, 1998, http://www.ann-geophys.net/16/90/1998/.

Lawrence, M. and Rasch, P. J.: Tracer transport in deep convective updrafts: Plume ensemble versus bulk formulations, J. Atmos. Sci., 62, 2880-2894, 2005.

Leriche, M., Cautenet, S., Barth, M., and Chaumerliac, N.: Modelling of the July 10 STERAO storm with the RAMS model: Chemical species redistribution including gas phase and aqueous phase chemistry, in: Air Pollution Modeling and Its Application XVIII, edited by: Borrego, C. and Renner, E., pp. 433-442, Elsevier, Amsterdam, The Netherlands, 2007.

Lipps, F. B. and Hemler, R. S.: Numerical simulations of deep tropical convection associated with large-scale convergence, J. Atmos. Sci., 43, 1796-1816, 1986.

Lin, Y-L, Farley, R. D., and Orville, H. D.: Bulk parameterization of the snow field in a cloud model, J. Clim. Appl. Meteorol., 22, 1065-1092, 1983.

MacGorman, D. R. and Rust, W. D.: The Electrical Nature of Storms, Oxford University Press, 422 pp., 1998.

Madronich, S.: Photodissociation in the atmosphere: 1. Actinic fluxes and the effects of ground reflections and clouds, J. Geophys. Res., 92, 9740-9752, 1987.

Madronich S. and Flocke, S.: The role of solar radiation in atmospheric chemistry, in: Handbook of Environmental Chemistry, edited by: Boule, P., 1-26, Springer, New York, 1999.

Meyers, M. P., Walko, R. L., Harrington, J. Y., and Cotton, W. R.: New RAMS cloud microphysics parameterization. Part II: The two moment scheme, Atmos. Res., 45, 3-39, 1997.

Ovtchinnikov, M. and Ghan, S. J.: Parallel simulations of aerosol influence on clouds using cloud-resolving and 
single-column models, J. Geophys. Res., 110, D15S10, doi:10.1029/2004JD005088, 2005.

Pickering, K. E., Thompson, A. M., Wang, Y. S., Tao, W. K., McNamara, D. P., Kirchhoff, V. W. J. H., Heikes, B. G., Sachse, G. W., Bradshaw, J. D., Gregory, G. L., and Blake, D. R.: Convective transport of biomass burning emissions over Brazil during TRACE A, J. Geophys. Res., 101, 23 993-24 012, 1996.

Pickering, K. E., Wang, Y., Tao, W.-K., Price, C., and Müller, J.-F.: Vertical distributions of lightning $\mathrm{NO}_{x}$ for use in regional and global chemical transport models, J. Geophys. Res., 103, 31203 $31212,1998$.

Pinty, J.-P. and Jabouille, P.: A mixed-phase cloud parameterization for use in a mesoscale non-hydrostatic model: Simulations of a squall line and of orographic precipitation, in: Conf. On Cloud Physics, Everett, WA, Amer. Meteorol. Soc., 217-220, 1998.

Popp, P. J. Gao, R. S., Marcy, T. P., Fahey, D. W., Hudson, P. K., Thompson, T. L., Kärcher, B., Ridley, B. A., Weinheimer, A. J., Knapp, D. J., Montzka, D. D., Baumgardner, D., Garrett, T. J., Weinstock, E. M., Smith, J. B., Sayres, D. S., Pittman, J. V., Dhaniyala, S., Bui, T. P., and Mahoney, M. J.: Nitric acid uptake on subtropical cirrus cloud particles, J. Geophys. Res., 109, D06302, doi:10.1029/2003JD004255, 2004.

Price, C. and Rind, D.: A simple lightning parameterization for calculating global lightning distributions, J. Geophys. Res., 97, 9919-9933, 1992.

Price, C., Penner, J., and Prather, M.: $\mathrm{NO}_{\mathrm{x}}$ from lightning 1. Global distribution based on lightning physics, J. Geophys. Res., 102, 5929-5941, 1997.

Ridley, B. A., Walega, J. G., Dye, J. E., and Grahek, F. E.: Distributions of $\mathrm{NO}, \mathrm{NO}_{\mathrm{x}}, \mathrm{NO}_{\mathrm{y}}$, and $\mathrm{O}_{3}$ to $12 \mathrm{~km}$ altitude during the summer monsoon season over New Mexico, J. Geophys. Res., 99, 25 519-25 534, 1994.

Rutledge, S. A., Hegg, D. A., and Hobbs, P. V.: A numerical model for sulfur and nitrogen scavenging in narrow cold-frontal rainbands, 1, Model description and discussion of microphysical fields, J. Geophys. Res., 91, 14 385-14 402, 1986.

Schwartz, S. E.: Mass-transport considerations pertinent to aqueous phase reactions of gases in liquid-water clouds, in: Chemistry of Multiphase Atmospheric Systems, edited by: Jaeschke, W., Springer-Verlag, New York, 415-471, 1986.

Seinfeld, J. H.: Atmospheric Chemistry and Physics of Air Pollution, John Wiley \& Sons, New York, 768 pp, 1986.

Seifert A. and Weisman, M.: A comparison of bulk microphysical schemes for cloud resolving NWP, in: Proceedings of the 6th WRF/15th MM5 Users' Workshop, Boulder, Colorado, http://www.mmm.ucar.edu/wrf/users/workshops/ WS2005/abstracts/Session6/2-Seifert.pdf, 2005.

Skamarock, W. C., Powers, J., Barth, M. C., Dye, J. E., Matejka, T., Bartels, D., Baumann, K., Stith, J., Parrish, D. D., and Hubler, G.: Numerical simulations of the 10 July STERAO/Deep Convection Experiment convective system: Kinematics and transport, J. Geophys. Res., 105, 19973-19990, 2000.

Skamarock, W. C., Dye, J. E., Defer, E., Barth, M. C., Stith, J. L., Ridley, B. A., and Baumann, K.: Observational- and modeling-based budget of lightning-produced $\mathrm{NO}_{\mathrm{x}}$ in a continental thunderstorm, J. Geophys. Res., 108(D10), 4305, doi10.1029/2002JD002163, 2003.

Skamarock, W. C, Klemp, J. B., Dudhia, J., Gill, D., Barker, D., Wang, W., and Powers, J. G.: A description of the Advanced
Research WRF Version 2., Technical Note NCAR/TN-468+STR, NCAR, Boulder, Colorado, 2005.

Smolarkiewicz, P. K.: A full multidimensional positive definite advection transport algorithm with small implicit diffusion, J. Comput. Phys., 65, 325-363, 1984.

Smolarkiewicz, P. K. and Clark, T. L.: The multidimensional positive definite advection transport algorithm. Further development and applications, J. Comput. Phys., 67, 394-439, 1986.

Smolarkiewicz, P. K. and Grabowski, W. W.: The multidimensional positive advection transport algorithm: Nonoscillatory option, J. Comp. Phys., 86, 355-375, 1990.

Snow, J. A., Heikes, B. G., Shen, H., O'Sullivan, D. W., Fried, A., and Walega, J.: Hydrogen peroxide, methyl hydroperoxide, and formaldehyde over North America and the North Atlantic, J. Geophys. Res., 112, D12S07, doi:10.1029/2006JD007746, 2007.

Soong, S.-T. and Ogura, Y.: Response of trade wind cumuli to largescale processes, J. Atmos. Sci., 37, 2035-2050, 1980.

Spiridonov, V. and Curic, M.: A three-dimensional numerical simulation of sulfate transport and redistribution, Can. J. Phys., 81, 1067-1094, 2003.

Spiridonov, V. and Curic, M.: The relative importance of scavenging, oxidation, and ice-phase processes in the production and wet deposition of sulfate, J. Atmos. Sci., 62, 2118-2135, 2005.

Stenchikov, G., Dickerson, R., Pickering, K., Ellis, W., Doddridge, B., Kondragunta, S., Poulida, O., Scala, J., and Tao, W. K.: Stratosphere-troposphere exchange in a midlatitude mesoscale convective complex .2. Numerical simulations, J. Geophys. Res., 101, 6837-6851, 1996.

Stevens D. E. and Bretherton C. S.: A forward-in-time advection scheme and adaptive multilevel flow solver for nearly incompressible atmospheric flow, J. Comp. Phys., 129, 284-295, 1996.

Stickler, A., Fischer, H., Williams, J., de Reus, M., Sander, R., Lawrence, M. G., Crowley, J. N., and Lelieveld, J.: Influence of summertime deep convection on formaldehyde in the middle and upper troposphere over Europe, J. Geophys. Res., 111, D14308, doi:10.1029/2005JD007001, 2006.

Taghavi, M., Cautenet, S., and Foret, G.: Simulation of ozone production in a complex circulation region using nested grids, Atmos. Chem. Phys., 4, 825-838, 2004, http://www.atmos-chem-phys.net/4/825/2004/.

Tao, W.-K. and Simpson, J.: Goddard Cumulus Ensemble model. Part I: Model description, TAO, 4, 35-72, 1993.

Tao, W.-K., Simpson, J., Baker, D., Braun, S., Chou, M.-D., Ferrier, B., Johnson, D., Khain, A., Lang, S., Lynn, B., Shie, C.-L., Starr, D., Sui, C.-H., Wang, Y., and Wetzel, P.: Microphysics, radiation, and surface processes in the Goddard Cumulus Ensemble (GCE) model, Meteorol. Atmos. Phys., 82, 97-137, 2001.

Taylor, G. R.: Sulfate production and deposition in midlatitude continental cumulus clouds. Part II: Chemistry model formulation and sensitivity analysis, J. Atmos. Sci., 46, 1991-2007, 1989.

Tost, H., Jockel, P., and Lelieveld, J.: Influence of different convection parameterizations in a GCM, Atmos. Chem. Phys., 6, 54755493, 2006, http://www.atmos-chem-phys.net/6/5475/2006/.

Tripoli, G. J. and Cotton, W. R.: The use of ice-liquid water potential temperature as a thermodynamical variable in deep atmospheric models, Mon. Weather Rev., 109, 1094-1102, 1981.

Tripoli, G. J. and Cotton, W. R.: The Colorado State University 
three-dimensional cloud/mesoscale model - 1982, Part II: An ice phase parameterization, J. Rech. Atmos., 16, 295-320, 1982.

Wang, C.: A modeling study on the response of tropical deep convection to the increase of $\mathrm{CCN}$ concentration. 1. Dynamics and microphysics, J. Geophys. Res., 110, D21211, doi:10.1029/2004JD005720, 2005a.

Wang, C.: A modeling study on the response of tropical deep convection to the increase of $\mathrm{CCN}$ concentration. 2 . Radiation and chemistry, J. Geophys. Res., 110, D22204, doi:10.1029/2005JD005829, 2005b.

Wang, C. and Chang, J.: Three-dimensional numerical model of cloud dynamics, microphysics, and chemistry 1 . Concepts and formulation, J. Geophys. Res., 98(D8), 14 827-14 844, 1993a.

Wang, C. and Chang, J.: A three-dimensional numerical model of cloud dynamics, microphysics, and chemistry 3. Redistribution of pollutants, J. Geophys. Res., 98(D9), 16787-16 798, 1993 b.

Wang, C. and Chang, J.: A three-dimensional numerical model of cloud dynamics, microphysics, and chemistry 4. Cloud chemistry and precipitation chemistry, J. Geophys. Res., 98(D9), 16799-16808, 1993c.

Wang, C. and Crutzen, P. J.: Impact of a simulated severe local storm on the redistribution of sulfur dioxide, J. Geophys. Res., 100(D6), 11357-11367, 1995.

Wang, C. and Prinn, R.: On the roles of deep convective clouds in tropospheric chemistry, J. Geophys. Res., 105(D17), 22269 22298,2000
Wang, C., Prinn, R. G., and Sokolov, A.: A global interactive chemistry and climate model: Formulation and testing, J. Geophys. Res., 103(D3), 3399-3418, 1998a.

Wang, Y., DeDilva, A. W., Goldenbaum, G. C., and Dickerson, R. R.: Nitric oxide production by simulated lightning: Dependence on current, energy, and pressure, J. Geophys. Res., 103(D15), 19 149-19 160, doi:10.1029/98JD01356, 1998b.

Wicker, L. J. and Skamarock, W. C.: Time-splitting methods for elastic models using forward time schemes, Mon. Weather Rev., 130, 2088-2097, 2002.

Xie, S, Xu, K.-M., Cederwall, R. T., Bechtold, P., Genio, A. D. D., Klein, S. A., Cripe, D. G., Ghan, S. J., Gregory, D., Iacobellis, S. F., Krueger, S. K., Lohmann, U., Petch, J. C., Randall, D. A., et al.: Intercomparison and evaluation of cumulus parametrizations under summertime midlatitude continental conditions, Q. J. Roy. Meteor. Soc., 128, 1095-1135, 2002.

Zhang, X., Helsdon Jr., J. H., and Farley, R. D.: Numerical modeling of lightning-produced $\mathrm{NO}_{\mathrm{x}}$ using an explicit lightning scheme: 2. Three-dimensional simulation and expanded chemistry. J. Geophys. Res., 108(D18), 4580, doi:10.1029/2002JD003225, 2003. 